\title{
The Impact of Social Beliefs on Microfinance Performance
}

OLLE BERGGREN | KATARZYNA BURZYNSKA

KNUT WICKSELL WORKING PAPER 2014:5

\section{Working papers}

Editor: F. Lundtofte The Knut Wicksell Centre for Financial Studies

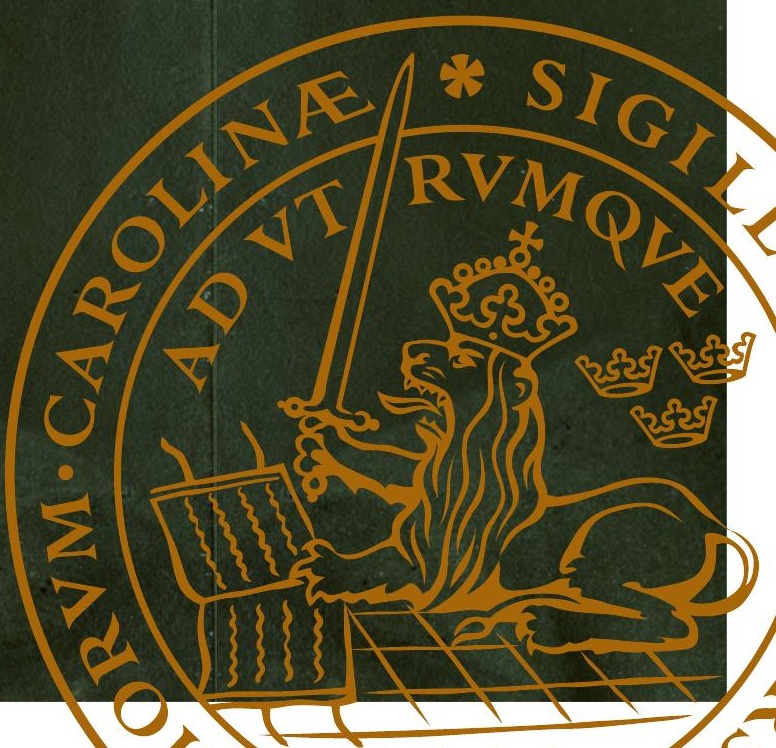





\title{
The Impact of Social Beliefs on Microfinance
}

\section{Performance* $^{*}$}

\author{
August 2014 \\ Olle Berggren \\ Department of Economics, Uppsala University, Box 513, 75120 Uppsala, \\ Sweden. E-Mail: olle.berggren@nek.uu.se
}

\begin{abstract}
Katarzyna Burzynska ${ }^{\dagger}$
Department of Economics and Knut Wicksell Centre for Financial Studies, Lund University, Box 7082, 22007 Lund, Sweden.

E-Mail: katarzyna.burzynska@nek.lu.se

Telephone: +46 (0)46 2224290

Fax: +46 (0)46 2224118
\end{abstract}

\footnotetext{
${ }^{*}$ We gratefully acknowledge the helpful comments of Sonja Opper and Frederik N.G. Andersson. We also thank participants at the Workshop on Banking and Finance in Emerging Markets in Strasbourg, the PhD Nordic Finance Workshop in Stockholm, the $6^{\text {th }}$ IFABS Conference in Lisbon and the Comparative Institutional Analysis research group seminars at Lund University.

${ }^{\dagger}$ Corresponding author
} 


\begin{abstract}
We apply a panel of 331 microfinance institutions from 37 countries to investigate the relationship between social beliefs and microfinance financial performance. We find that microfinance institutions in countries with higher levels of trust and more collectivist culture have lower operating and default costs and charge lower interest rates. These results provide the first large cross-country evidence that social beliefs are important determinants of microfinance performance.
\end{abstract}

Keywords: microfinance; performance; informal institutions; trust; collectivism JEL: O16; O17; O50; G21, O43 


\section{INTRODUCTION}

Since the late 1980s, microfinance institutions (MFIs) have developed as a key way to solve the financial exclusion problem of poor people in developing countries, and the so-called 'microfinance revolution' quickly gained popularity around the world. ${ }^{1}$ Both theory and empirical studies suggest that financial exclusion can hamper economic development and lead to persistent income inequality (Banerjee \& Newman, 1993; Ray, 1998). The major advantage of MFIs is thus to ensure easier access to credit services through the offering of small loans without monetary or physical collateral demands. Nevertheless, there is a substantial variation between countries in terms of the success and performance of MFIs (Armendáriz \& Morduch, 2010; Cull, Demirgüç-Kunt, \& Morduch, 2007).

Various cross-country studies have attempted to explain the uneven microfinance performances by differences in economic and organizational indicators, such as MFIs' legal status, regulation and corporate governance (Cull, Demirgüç-Kunt, \& Morduch, 2011; Hartarska \& Nadolnyak, 2007; Mersland \& Strøm, 2009; Roberts, 2013). More recently, microfinance studies also started to take the impact of formal institutional arrangements into account These studies suggest that MFIs may perform better in countries where the traditional financial system is underdeveloped (Vanroose \& D'Espallier, 2013) and where formal institutions are weak (Ahlin, Lin, \& Maio, 2011).

We take the analysis one step further and shift attention to informal arrangements. Because MFIs imitate informal lending practices and rely strongly on personalised interactions and communal norms, their operations should be deeply embedded in a country's social and cultural context (Epstein \& Yuthas, 2011). Through the use of group lending and social collateral, microfinance is therefore likely to rely more on informal institutions such as trust rather than on the formal institutional environment. Building on this informal institutional 
perspective, we examine the role of social beliefs on MFIs' operational and financial performance across countries. To our knowledge, this study provides the first large crosscountry analysis of the impact of social beliefs on microfinance performance.

For the purpose of this study, we construct a dataset of 311 MFIs located in 37 countries based on the information provided by the Microfinance Information Exchange (MIX, 2012), which we complement with survey data on trust from the World Values Survey (WVS, 2012) and the Global Barometer Surveys (GBS, 2009) as well as the individualism versus collectivism index developed by Hofstede, Hofstede and Minkov (2010). To distinguish the impact of social beliefs from that of other factors, we select a large set of control variables based on previous studies and theoretical considerations.

We find evidence in support of our hypothesis that social beliefs affect MFIs' financial performance. Our results show that MFIs in countries with higher levels of trust have significantly lower default risks and charge lower interest rates. Moreover, a higher degree of collectivist cultural values is associated with significantly lower costs per borrower and costs per dollar loaned. Ancillary tests indicate that while the effect of collectivism is most significant for smaller MFIs, the positive correlation between trust and MFI financial performance holds for MFIs of all sizes.

The remainder of this paper proceeds as follows. In Chapter 2, we explain the relationship between MFI performance and social beliefs and develop our hypotheses. In Chapter 3, we describe the dataset and discuss the choice of variables. In Chapter 4, we present the methodology. In Chapter 5, we report the results on the relationship between MFI performance and social beliefs. Finally, Chapter 6 concludes the paper. 


\section{MICROFINANCE AND SOCIAL BELIEFS}

The idea that informal institutions, such as culture, customs, beliefs, norms and religion, affect organizational performance is strongly supported by a wide range of theoretical and empirical studies (Ménard \& Shirley, 2005; Williamson, 1998). In our paper, we focus particularly on trust and collectivist cultural norms. Microfinance lending schemes rely on collective action, cooperation and coordination for mutual benefit, all of which depend strongly on reciprocity and trust (Beilmann \& Realo, 2012). We therefore conjecture that the level of trust as well as the degree of collectivist cultural norms, as features of communities and nations, should have a pivotal role in the development and performance of microfinance.

\section{(a) Trust}

Trust plays an important role in any type of financial exchange, and while formal contracts and legal regulations can serve as its substitute, they come at the expense of transaction costs (Howorth \& Moro, 2012). Because trust is present at multiple levels of interactions within microfinance relationships, both between borrowers and between borrowers and loan officers, its amount can critically affect the outcomes (Epstein \& Yuthas, 2011). MFIs can use trust to minimise the need for formal contracts and regulations and to serve as an alternative control mechanism. This allows an MFI to save money and resources on transaction and monitoring costs, to provide lower interest rates and, eventually, to fulfil its mission to offer financial services to the poorest and most disadvantaged clients.

Moreover, microfinance repayment relies on joint liability, social connections, informal networks and other features of informal group lending schemes, implying that MFIs operate in a credit market that relies on credible promises instead of formal collateral. Trust and social collateral, which encompasses borrowers' reputation and the social networks to which they 
belong, can solve problems of imperfect information and credible commitment (Karlan, Mobius, Rosenblat, \& Szeidl, 2009; Keefer \& Knack, 2005). Peer pressure, joint liability and the threat of social sanctions can decrease the risks of opportunistic behaviour by contracting parties, while social connections between borrowers promote savings in screening and mutual monitoring (Bastelaer \& Leathers, 2006). Consequently, the higher the level of trust, the better the MFI performance should be.

Epstein and Yuthas (2011) develop a theoretical model that incorporates trust as an important determinant of MFI performance. The positive impact of higher levels of trust on MFI performance is explained by three main mechanisms. First, trust motivates borrowing group members to cooperate and to share information and resources, which increases loan repayment (Bastelaer \& Leathers, 2006; Karlan, 2007). Second, trust improves the sustainability of borrowing groups over time, thus decreasing the risk of default (McEvily, Perrone, \& Zaheer, 2003). Third, trust is necessary in order to form the relationship between loan officers and clients and for loan officers to obtain important information from clients, which in turn allows loan officers to charge lower interest rates (Uchida, Udell, \& Yamori, 2012).

Previous experimental and country-specific micro-level studies also suggest that social ties can reduce moral hazard behaviour within groups (for example, Hermes, Lensink, \& Mehrteab, 2005, in Eritrea) and that clients with stronger social connections, a similar culture and higher trust tend to have higher repayment rates (Al-Azzam, Hill, \& Sarengi, 2012, in Jordan; Bastelaer \& Leathers, 2006, in Zambia; Cassar, Crowly, \& Wydick, 2007, in South Africa and Armenia; Karlan, 2007, in Peru). If such relationships exist on the micro level, there is reason to believe that they should also be decisive in explaining variation in crosscountry comparisons of organizational performance. 
Given the above-discussed benefits of higher trust, we propose the following hypothesis:

Hypothesis 1: The higher a country's level of trust:

a) the higher its MFI repayment rates,

b) the lower its MFI costs, and

c) the lower its MFI interest rates.

\section{(b) Collectivist cultural norms}

Another important dimension of social beliefs is that of cultural variation, particularly the aspect of collectivist versus individualist cultural norms (Markus \& Kitayama, 1991). In more collectivist societies, individuals are more willing to subordinate their personal goals to collective ones and regard themselves as strongly connected with other members of the group. In contrast, individuals in more individualistic societies see each other as autonomous beings pursuing their personal goals (Oyserman, Coon, \& Kemmelmeier, 2002).

The sociocultural environment in which MFIs operate, which includes obligations, expectations, norms and self-imposed rules of conduct, can influence financial management and the choice of guarantors, thus affecting MFI lending practices. In a highly collectivist country, where obligations to the well-being of the extended family and kinship network are valued higher than the individual's private benefit, group welfare is part of the individual member's self-identity and reputation. As such, individuals in more collectivist countries not only work hard to repay their own debts but also encourage other group members to do the same (Gould, 2010).

Moreover, compared to individualist societies, collectivist societies rely more on informal institutions, which can allow MFIs to take better advantage of the existing informal environment. Collectivist cultural norms enhance the group's ability to use the threat of non- 
financial social and moral sanctions against the individual group member, which in turn should reduce moral hazard and lead to lower default rates in repayment (Greif, 1994). With improved peer monitoring and the increased effectiveness of peer pressure as an enforcement mechanism, MFIs in collectivist societies should be able to achieve higher repayment rates, reduce operating costs and charge lower interest rates. This is also supported by a comparative study of microfinance in Bangladesh and the United States, in which Gould (2010) attributes the relative success of Bangladeshi MFIs to their reliance on collectivist cultural norms, which are stronger in Bangladesh compared to the United States.

Our second hypothesis is therefore the following:

Hypothesis 2: The higher a country's degree of collectivist cultural norms:

a) the higher its MFI repayment rates,

b) the lower its MFI costs, and

c) the lower its MFI interest rates.

\section{DATA}

\section{(a) MFI data}

Our MFI performance data come from the MIX Market database (2012). The MIX Market reports data from approximately 2,000 MFIs from more than 100 countries. We focus on the period 2003-2011 and match these data with the available information on social beliefs. Due to concerns about the reliability of self-reported data such as that provided by the MIX Market, we decide to base our study on MFI reports that are audited by a third party and to only include observations that correspond to a calendar-year fiscal year (as in Ahlin et al., 2011). Moreover, we require each institution to be exclusively focused on microfinance, that 
is, the percentage of its operations composed of microfinance to be 80 per cent or higher. Finally, in our analysis, we only include observations of the dependent variables that are available for at least four consecutive years (as in Ahlin et al., 2011; Mersland, D’Espallier, \& Supphellen, 2013; Roberts, 2013). In all, this leaves us with 331 MFIs from 37 countries with available information on both social beliefs and MFI performance.

Our sample coverage is not geographically balanced, which relates to the fact that MFIs are mostly active in developing countries with relatively low levels of financial and economic development. ${ }^{2}$ Nevertheless, there is a fair degree of variation between those countries, not only in terms of social beliefs but also in terms of economic and financial development. These countries range from Ethiopia, with a gross domestic product (GDP) per capita of 341 US dollars in 2010, to Chile, with a GDP per capita of 12,671 US dollars. Zambia has the lowest level of financial development, with domestic credit to the private sector at 12 per cent of GDP in 2010, while China ranks at the top, with domestic credit to the private sector at 130 per cent of GDP.

Because social beliefs are hypothesised to facilitate MFI transactions by raising repayment rates and reducing costs to both lenders and borrowers, our main dependent variables are the commonly used drivers of MFI financial performance, namely, the average interest rate, cost per borrower, cost per dollar loaned and portfolio at risk. Following Ahlin et al. (2011), we calculate the average interest rate as the ratio of financial revenue to the average gross loan portfolio, and we calculate the cost per borrower as the ratio of operating expenses to the average number of active borrowers. ${ }^{3}$ As an indicator of default problems, we use the standard international measure of portfolio quality, that is, portfolio at risk (PAR30), which is the fraction of the loan portfolio overdue for more than thirty days. 
Following Ahlin et al. (2011), we control for the following MFI-specific characteristics: age, institutional type, and size decomposed into the number of active borrowers, the average loan size, and the ratio of assets to loans. ${ }^{4}$ Table 1 presents the summary statistics of the MFI variables used in the analysis. In total, we consider 331 MFIs, of which 44 per cent are operating under non-governmental organization (NGO) status, 31 per cent are registered as non-bank financial institutions (NBFIs), 11 per cent as cooperatives or credit unions, 9 per cent as commercial banks and 4 per cent as rural banks. To evaluate the representativeness of this sample, we compare it to the broader sample used by Ahlin et al. (2011). With median MFI having an average loan size of 1,013 dollars and charging an average interest rate of 35 per cent, we find our sample very similar.

[TABLE 1]

\section{(b) Social beliefs}

Our two key measures of social beliefs are trust and the value of collectivism relative to individualism in a society. The most common measure of trust applied in cross-country studies is based on the standard survey question 'Generally speaking, would you say that most people can be trusted or that you need to be very careful in dealing with people?' and uses the percentage of people who answer, 'most people can be trusted' as an indicator of the country's general level of trust. ${ }^{5}$ The three latest waves of the WVS (2012) cover the period 1995-2008 and provide information on 44 countries matching our MFI data, while the GBS (2009) provides data on 24 additional countries over the period $1995-2010 .^{6}$ The data are matched with available information on collectivism, which leaves us with 37 countries. Within this sample, the countries with the highest levels of trust are China (with an average trust score of $56 \%$ ), Pakistan (40\%), Vietnam (39\%) and Jordan (32\%), while Brazil (7\%), the 
Philippines (10\%), Kenya (10\%) and Tanzania (11\%) are the countries with the lowest trust scores (see Table Al in the Appendix).

We base our indicator of the collectivism versus individualism cultural dimension on the survey-based individualism index (IDV) developed by Hofstede et al. (2010). This individualism index is the most commonly used measure of collectivism and has been validated in a number of studies (for example, Chui, Titman, \& Wei, 2010; Weber, Shenkar, $\&$ Raveh, 1996). The original index takes values from 0 to 100 , where a high value indicates a high degree of individualism and a low value indicates a high degree of collectivism. For the convenience of easier interpretation of the results, we subtract the IDV's original values from 100 such that a high value indicates a high degree of collectivism and a low value indicates a high degree of individualism. Within our sample, the countries characterised by the highest collectivism values are Guatemala (with a collectivist score of 94 points), Ecuador (92 points), Panama (89 points) and Colombia (87 points), while Argentina (54 points), Lebanon (60 points), Russia (61 points) and Brazil (62 points) are the most individualist ones (see Table Al in the Appendix).

The summary statistics of the social beliefs variables are presented in Table 2, together with the description of the other country-specific variables used in the analysis.

[TABLE 2]

\section{(c) Country-specific variables}

In addition to social beliefs and MFI characteristics, we explore a large number of other variables used in the literature to explain cross-country variation in MFI performance.

Existing empirical research on MFIs suggests that their financial performance is related to the macroeconomic and institutional environment in which they operate (Ahlin et al. 2011). We 
use per capita economic growth and GDP per capita to account for a country's economic situation (as in Ahlin et al., 2011; Hartarska \& Nadolnyak, 2007; Mersland et al., 2013). Because MFI performance is affected by access to the traditional financial system (Vanroose \& D'Espallier, 2013), we also include the ratio of private sector domestic credit to GDP (Private credit) as a determinant of financial sector development. Following Ahlin et al. (2011), we further control for the prevalence of labour opportunities in the economy using the ratio of the total labour force to the population aged 15 and above (Laborforce) and the manufacturing value added to GDP ratio (Manufacturing). All of the economic control country-level data come from the World Bank's World Development Indicators (WDI, 2013).

To control for the formal institutional setting, we consider a number of indicators, including the rule of law, control of corruption, regulatory quality and political stability indicators, from the World Bank's Worldwide Governance Indicators (WGI, 2013).

Another concern is that the level of a society's cultural heterogeneity can potentially drive the indicators of social beliefs and therefore affect our outcome variables (Glaeser, Laibson, Sheinkman, \& Soutter, 2000). To account for this, we complement our set of base controls with a measure of ethnic fractionalization. The ethnic fractionalization index comes from Alesina, Devleeschauwer, Easterly, Kurlat and Wacziarg (2003), in which a higher value indicates a higher degree of fractionalization within the country.

A larger set of country controls encompasses various aspects of institutional conditions that could be potentially correlated with social beliefs and MFI financial outcomes. First, based on the study by Acemoglu, Johnson and Robinson (2001), we construct a dummy indicating whether a country is a former colony or not, of which 84 per cent of the countries included in our sample are. We also consider the natural logarithm of settler mortality as a proxy for the degree of extractive institutions and the protection against risk of expropriation index as an 
alternative proxy for the quality of current institutions. Second, a country's score on the Heritage Foundation's (2013) Index of Economic Freedom serves as a proxy for the development of market institutions. Based on 2010 country evaluations of this index, we construct a dummy indicating whether a country is considered to have a 'mostly unfree' economy, of which 60 per cent of the countries in our sample do. ${ }^{7}$ Third, we group countries according to their 2010 income levels into low-income, lower-middle income or upper-middle

income countries based on the World Bank's (2013) classification. ${ }^{8}$ Upper-middle income countries dominate our sample, followed by lower-middle income countries. Fourth, La Porta, Lopez-de-Silanes, Shleifer and Vishny (1999) and Beck, Demirgüç-Kunt and Levine (2003b) suggest that national legal traditions are correlated with certain characteristics of financial systems, such as the access to equity finance and the government ownership of banks, and thus influence their development. To control for this aspect, we include dummies for English common law, French civil law, and socialist law. Fifth, from the study by La Porta et al. (1999), we also obtain another aspect of culture, that is, the percentage of the population in each country belonging to different religious affiliations separated between Catholic, Protestant, Muslim and others. Finally, we investigate whether our measures of social beliefs could capture the general effect of poverty. As a proxy for poverty, we use the average levels of the poverty headcount ratio at 2 dollars per day, based on the WDI (World Bank, 2013). ${ }^{9}$ The percentage of the population below the poverty line varies in our sample from less than 1 per cent in Russia to approximately 80 per cent in Tanzania.

\section{ESTIMATION METHODOLOGY}

Empirical analyses of MFI performance usually specify performance as a function of MFIspecific variables as well as macroeconomic and institutional factors (Ahlin et al., 2011; 
Hartarska \& Nadolnyak, 2007; Mersland et al., 2013), which we complement with social beliefs. Formally, the estimated equation takes the following form:

$$
y_{i j t}=\alpha+\beta_{S} S_{j t}+\beta_{M} M_{j t}+\beta_{X} X_{i t}+u_{i j t}
$$

where $y_{i j t}$ is the performance variable for MFI $i$ in country $j$ at time $t ; S_{j t}$ captures the impact of social beliefs; $M_{j t}$ are macroeconomic and formal institutional country-specific variables; $X_{i t}$ is a vector of MFI-specific variables; and $u_{i j t}$ is an error term.

Our main performance indicators are interest rates, operating costs and default rates, while trust and collectivism are the focal explanatory variables. In our baseline specification, we then follow Ahlin et al. (2011). Macroeconomic controls consist of GDP per capita growth, labour force participation, manufacturing share, private credit, and lagged levels of GDP per capita in linear and quadratic forms. We add rule of law as a proxy for formal institutional development. Finally, we include age, institutional-type dummies, and a lagged number of borrowers, average loan size and assets per loan as MFI control variables.

Our initial analysis of the data reveals the presence of severe outliers and indicates that the residuals are not normally distributed. We therefore follow Ahlin et al. (2011) and estimate the model using a quantile regression, which has several useful properties. First, its objective function is a weighted sum of absolute deviations, which gives a vector of coefficients that are robust to outlier observations (Koenker \& Bassett, 1978). ${ }^{10}$ Second, when the standard assumption of normality of the error term does not hold, quantile regression estimators are more efficient than least square estimators (Buchinsky, 1998). Finally, in contrast to ordinary least squares, which estimate the mean effect of explanatory variables, quantile regression allows for estimations of the entire conditional distribution of the dependent variable. By calculating coefficient estimates at various quantiles of the conditional distribution, we are 
therefore able to study the effects of social beliefs on MFIs with varying levels of financial performance.

We compute standard errors robust to heteroskedasticity and misspecification following Angrist, Chernozhukov and Fernández-Val (2006). Furthermore, because within-MFI standard errors can be correlated due to MFI-specific shocks, we verify the need to cluster standard errors at the MFI level by testing for intra-cluster correlation using the Parente and Santos Silva (2013) test. In the case of detected intra-cluster correlation, we compute robust standard errors as proposed by Parente and Santos Silva (2013), which serve as an alternative to bootstrap, offering faster computation times.

\section{EMPIRICAL RESULTS}

\section{(a) Baseline results of the impact of social beliefs on MFI performance}

We first determine the appropriate model specification by testing for intra-cluster correlation using the Parente and Santos Silva (2013) test. The results of this test indicate that there is intra-cluster correlation. We therefore apply standard errors that are robust under heteroskedasticity and intra-cluster correlation. Table 3 presents the estimation results obtained from the quantile regression with robust standard errors clustered on MFI.

\section{[TABLE 3]}

As shown in Table 3, we find a significant negative correlation between trust and default risk. That is, the fraction of actual loans at risk in MFI portfolios is significantly lower in countries where there is higher trust. A value of -0.146 suggests that the PAR30 of MFIs in countries with higher levels of trust is typically 0.146 percentage points lower. This is consistent with 
Hypothesis $1 a$, implying that trust improves microloan default rates by strengthening the borrowers' repayment discipline. Contrary to our expectations in Hypothesis $1 \mathrm{~b}$, we do not find significant effects of trust on MFI operating costs. Consistent with Hypothesis $1 c$, however, there is a significant negative correlation between a country's level of trust and MFIs' average interest rates, indicating that microcredit is less expensive for borrowers in higher-trust societies. An additional percentage point of trust is associated with a 0.341 percentage point lower average interest rate. This result is consistent with the findings of Howorth and Moro (2012), which show that trust decreases the cost of bank credit for small businesses. By reducing transaction and agency costs, higher trust can also influence the lending decisions of MFI loan officers, encouraging them to offer lower interest rates to their clients.

Contrary to Hypothesis $2 a$, collectivism seems to be related to higher default rates. The estimated effect, however, is small, with MFIs in more collectivist countries having 0.001 percentage points higher PAR30. ${ }^{11}$ Consistent with Hypothesis $2 b$, MFIs in more collectivist societies tend to have lower costs both in terms of cost per borrower and cost per dollar loaned. An additional point in the collectivism measure is associated with a reduction in the costs per borrower of 3.69 dollars and a reduction in the costs per dollar loaned of 0.3 basis points. These results are consistent with the view that MFIs in collectivist societies can benefit from the increased effectiveness of peer monitoring and peer pressure compared to those in more individualist countries. However, we find no support for Hypothesis $2 c$, as we do not find any significant relationship between collectivism and MFIs' average interest rates. This suggests that MFIs do not pass on the cost savings of having more collectivist cultural values in terms of lower interest rates to their customers. 
To rule out the possibility that our measures of trust or collectivism could capture the effect of a country's cultural homogeneity, we control for ethnic fractionalization in all of the regressions. Our results suggest that a society's heterogeneity has a significant negative effect on MFIs' cost per borrower only. A potential explanation for this is that with increased fractionalization, societies have larger informal sectors (Lassen, 2007), which in turn could increase competition among MFIs and thereby lead to lower costs. As for other controls, the main indicators of the macroeconomic environment have the expected sign, where both economic growth and financial development are significantly correlated with better MFI performance, as also found by Ahlin et al. (2011).

Even though we control for the economic environment, rule of law and ethnic heterogeneity in our model specifications, there is still a possibility that our measure of generalised trust is not exogenous. To address this potential omitted variable bias, we also consider a larger set of control variables, including services, agriculture and manufacturing shares of GDP, inflation and population below the poverty line. We add each of these variables, one at a time, to our baseline specification. Moreover, we check for possible time effects by estimating our base model with added time dummies. For each specification, the negative correlation between generalised trust and MFIs' average interest rates and default costs remains statistically significant and of the similar order of magnitude. Similarly, the negative correlation between collectivism and operating costs remains statistically unaffected.

\section{(b) Impact of social beliefs at different levels of the conditional distribution of MFI}

\section{performance indicators}

Quantile regression allows us to examine the role of social beliefs on performance indicators throughout their conditional distribution and thereby to extend our analysis from a median MFI to also cover the best- and worst-performing MFIs. 


\section{[FIGURE 1]}

Figure 1 presents the comparison of trust estimates for separate quantiles in the conditional distribution of the two performance indicators on which trust had a significant effect in the baseline regressions (that is, average interest rates and default costs). The effect of trust declines with higher levels of average interest rates. This result indicates that while MFIs that charge relatively low interest rates benefit from higher trust levels, MFIs with the highest interest rates are less affected. On the other hand, the effect of trust on default costs is strongest among MFIs that have the highest levels of portfolio at risk. Because the absolute values of parameter estimates increase through the quantiles, trust improves repayment rates in the worst-performing MFIs, thereby lessening the dispersion of possible MFI defaults across countries. It is worth noting that trust also has a significant negative effect on cost per dollar loaned below the median of its conditional distribution, hinting at an improved performance for MFIs with lower costs. This relationship, however, is not reflected in the cost per borrower, where the effect is insignificant across all quantiles.

\section{[FIGURE 2]}

Figure 2 presents the results for the individualism versus collectivism index. Again, we focus only on the significant relationships from the baseline results (in this case, cost per borrower and cost per dollar loaned). The magnitude of the effect of collectivism increases with the cost per borrower, the largest being at the median of the conditional distribution. Above the 60th quantile, the effect of collectivism decreases and becomes insignificant, suggesting that collectivism does not reduce costs within MFIs with the highest costs per borrower. A similar pattern appears when comparing the effect of collectivism for separate quantiles in the conditional distribution of the cost per dollar loaned, where the effect of collectivism increases with higher levels of costs per dollar loaned and then becomes insignificant above 
the 80th quantile. Because the effect of collectivism is insignificant in the uppermost quantiles, MFIs with the highest costs do not benefit from collective social norms.

\section{(c) Impact of social beliefs on performance of larger versus smaller MFIs}

Social beliefs are hypothesised to work best in small, close-knit communities, and their influence should wither as the group size increases. As such, we are interested in whether social beliefs can enhance the financial performance of smaller MFIs better than that of larger MFIs. To investigate whether social beliefs have different impacts across different MFI sizes, we divide our sample into two groups according to the number of active borrowers. An MFI is classified as large (small) if its number of borrowers is above (below) the sample median. ${ }^{12}$

\section{[TABLE 4]}

Table 4 presents the effect of trust on the average interest rates and portfolio at risk. Contrary to our expectations, we do not find differences in the significance of the trust effect between smaller and larger MFIs, and the magnitude of coefficients is similar. Trust therefore plays a significant role in reducing interest rates and the probability of loan defaults for MFIs of all sizes. ${ }^{13}$ This result is in line with those of La Porta, Lopez-de-Silanes, Shleifer and Vishny (1997), who argue that trust is especially important in supporting cooperation in larger organizations, and with those of Howorth and Moro (2012), who find significant effects of trust on the performance of small banks, which are more similar to larger MFIs. Therefore, the size of an MFI is not the main determinant of the effectiveness of trust.

\section{[TABLE 5]}

In contrast, collectivism clearly lowers the costs of smaller MFIs, while having no significant effect among larger MFIs (see Table 5). These results can be explained by cooperative norms being most effective for smaller groups or communities with long-standing relationships, 
where the sanctioning against violators of such norms is most severe, while trust can still play a significant role in more complex, multiple-network societies (Hechter \& Opp, 2001).

\section{(d) Impact of social beliefs on the performance of NGOs versus banking institutions}

In our baseline results, we control for the effect of legal status by including institutional type dummies (see Table 3). To determine whether our results hold for more specific groups of MFIs, we distinguish between NGOs, which are typically not regulated by a banking supervisory agency, and more formal, supervised banking institutions (banks and NBFIs).

\section{[TABLE 6]}

Table 6 reports the results of these split-sample regressions. Our findings indicate that the two organizational types of MFIs benefit from social norms in somewhat different ways. While both NGOs and banking institutions have better repayment rates thanks to higher trust, only banking institutions benefit from trust in terms of lowered interest rates. For NGOs, collectivism is associated with lower interest rates instead. As such, we find that more institutionalised organizations such as banks benefit more from trust, while NGOs rely more on collectivism, which seems reasonable given the more informal nature of NGOs compared to banking institutions.

\section{(e) Impact of social beliefs with alternative formal institutional variables}

When we control for trust and collectivist cultural norms, a 'good' formal institutional environment as proxied by the rule of law does not seem to play a significant role in the financial performance of MFIs. This result is consistent with those of Ahlin et al. (2011), who find the rule of law indicator to be insignificant for MFI performance. However, they also find some other institutional determinants to be detrimental to MFI performance. Because the rule of law is not the only possible proxy for the quality of formal institutions, we assess the 
robustness of our results to different aspects of formal institutions by replacing the rule of law with other governance indicators, including the control of corruption, regulatory quality, government effectiveness and political stability indicators from the WGI (World Bank, 2013). ${ }^{14}$ Table 7 presents the results with government effectiveness used as the alternative institutional determinant. ${ }^{15}$

\section{[TABLE 7]}

In contrast to Ahlin et al. (2011), we do not find any negative effects of formal institutional quality on MFI performance. In fact, these correlations only hold when social beliefs are not controlled. Once we include them in our analysis, the negative effects of the formal institutional setting on MFI performance disappear. Moreover, the beneficial effects of social beliefs on MFI performance remain significant under all alternative specifications.

\section{(f) Impact of social beliefs including historical heritage}

Recent studies stress the importance of colonial experience on current institutions (Beck et al., 2003a; Acemoglu et al., 2001; La Porta et al., 1999). In particular, colonization policies adopted by colonizing European countries depended on the conditions in the colonies and left long-lasting effects on the quality of institutions in now-independent states. The argument is that the colonizers created better institutions in environments in which they could settle safely. To explore the importance of this historical aspect, we control for extractive institutions using the logarithm of settler mortality as a proxy.

\section{[TABLE 8]}

As shown in Table 8, the effects of social beliefs on the costs per borrower and PAR30 hold both with and without settler mortality controls. Moreover, extractive institutions tend to have statistically significant negative effects on MFI performance by increasing interest rates and 
the costs per dollar loaned. Although the effect of trust on the average interest rate becomes insignificant, informal institutions might still be especially important for MFIs operating within extractive institutions working as a viable substitute for a more favourable environment. Indeed, if we include the interaction term between trust and settler mortality, we find that the more extractive the institutions are, the more trust lowers MFI costs, which is significant at the 5 per cent level. ${ }^{16}$ In an alternative specification, we control for political heritage by including dummies for legal origin and find the effects of social beliefs significant and of similar magnitude as in the baseline results (see Table 9).

\section{[TABLE 9]}

\section{(g) Impact of social beliefs including economic freedom and country income groups}

We further investigate if our results hold when we take the development of market institutions and the current economic situation into account. To control for the degree of economic freedom, we include a dummy indicating repressed, or 'mostly unfree,' economies, which we base on the Index of Economic Freedom 2010 (Heritage Foundation, 2013). The results are presented in Table 10.

\section{[TABLE 10]}

There is some indication that MFIs operating in the environments where there is less market freedom have lower interest rates and lower costs per dollar loaned. To control for country effects, we include dummies indicating those groups based on economic development, that is, low-income countries, lower-middle income countries and upper-middle income countries. These results are presented in Table 11.

[TABLE 11] 
MFIs in low-income countries charge lower interest rates and bear lower costs per dollar loaned compared to middle-income countries. Nevertheless, in both specifications, the effects of social beliefs on MFI performance remain significant. The better performance of MFIs in the poorest countries with less-developed market economies can be an indication that clients there are most dependent on MFI services, which improves the repayment discipline. Moreover, such economic environments can be more conducive for economic actors to rely on informal institutions.

\section{(h) Impact of social beliefs including religion}

Finally, religion could conducive be another possible determinant of MFI performance. Because Islamic principles generally prohibit interest, MFIs operating in such settings may report interest rates inaccurately. Furthermore, Mersland et al. (2013) find that Christian MFIs have significantly lower costs of funds and interest rates than secular ones. However, due to a high correlation between the religion indicators and trust, we cannot directly include them in the regressions. Instead, we exclude the four countries with the highest shares of Muslim populations (Jordan, Morocco, Pakistan and Senegal). Table 12 presents the results.

\section{[TABLE 12]}

Social beliefs continue to exert significant favourable influence on MFI performance, with only the effect of collectivism on the cost per dollar loaned being weakened, yet not eliminated. Similarly, the exclusion of the four countries with the highest shares of Christian populations does not qualitatively affect the results. ${ }^{17}$

\section{CONCLUSION}

Despite microfinance's strong similarity to informal, relationship-based lending and its deep embeddedness in social and cultural contexts, there has been little empirical analysis of the 
effects of social beliefs on MFI performance. To address this gap in the literature, we employ a dataset of 331 MFIs from 37 countries and combine it with cross-country survey data on trust and collectivism.

We find that social beliefs help explain the observed differences in the financial performance of MFIs over the investigated period, 2003-2011, even when the economic environment, quality of formal institutions, historical factors and ethnic fractionalization are taken into account. Our results show that there is a negative and statistically significant relationship between the level of trust in a country and MFIs' average interest rates and default costs. We also find a significant, negative relationship between collectivist cultural norms and MFIs' operating costs.

The evidence in this paper indicates that social beliefs have s significant effect on MFIs' performance, allowing them to save on monitoring and default costs and to offer lower interest rates to their clients. This is consistent with the idea that MFIs are able to take advantage of a society's higher level of trust and stronger collectivist cultural norms, which improve cooperation and increase the within-group sense of responsibility and to use them as viable substitutes for traditional, formal institutions.

Our findings provide further insights for MFI development across countries. First, MFI financial performance not only relies on the macroeconomic and formal institutional environment, as the current empirical literature suggests, but is also closely related to social beliefs, particularly trust and norms of cooperation. Therefore, the informal institutional setting in which an MFI is situated should be taken into account when evaluating MFI performance. Second, social beliefs are more important to MFI performance than the formal institutional setting, and more formal institutions are not necessarily detrimental to MFI performance if the informal setting is taken into account. This result can explain the negative 
effect of good regulations and government on MFI performance found by Ahlin et al. (2011). Third, our results confirm that social collateral, supported by trust and collectivist cultural norms, can work as a substitute for physical collateral in MFIs. Finally, our results suggest that it is advisable for MFIs operating in countries with weak social beliefs to develop appropriate strategies that help substitute for weak social norms of trust and cooperation. 


\section{ENDNOTES}

${ }^{1}$ From 2000 to 2011, the total number of MFIs increased from 218 to 1,529 , and the number of active borrowers increased from 9 million to 98 million according to the MIX Market database (2013).

${ }^{2}$ The regional distribution of our sample coverage includes 13 countries from Latin America and the Caribbean, 9 countries from Africa, 4 countries from East Asia and the Pacific, 4 countries from Eastern Europe and Central Asia, 4 countries from Middle East and North Africa, and 3 counties from South Asia (see Table A1 in the Appendix).

${ }^{3}$ We recalculate the cost per borrower in constant 2005 international dollars.

${ }^{4}$ All MFI size controls (that is, the average loan size, assets to loans ratio, and number of active borrowers) are converted to natural logarithms.

${ }^{5}$ We calculate the average trust scores when scores from more than one survey are available. As an alternative measure, we also use the latest available score for each country. This alternative measure is correlated with the average measure at 87 per cent and gives very similar results.

${ }^{6}$ The GBS (2009) database includes the Latinobarómetro (2012), the Afrobarometer (2009), the AsiaBarometer (2012), the East Asian Barometer (2009) and the Arab Barometer (2007). The surveys ask the same question as the WVS (2012) to approximately the same number of individuals in each country.

${ }^{7}$ The group of 'mostly unfree' economies remains largely unchanged during our investigation period 2003-2011.

${ }^{8}$ Group members remain largely unchanged during our investigation period 2003-2011. 
${ }^{9}$ An alternative measure is the poverty headcount ratio at 1.25 dollars a day, which gives similar results.

${ }^{10}$ For robustness, we drop 5 or 10 extreme outliers based on Cook's distance measure and run median regressions in each case. The main results hold.

11 The correlation becomes insignificant altogether if we exclude from our analysis those MFIs that provide information that they do not provide group loans (giving us a subsample of 99 MFIs that certainly offer group loans). A potential interpretation of this may be that a higher degree of individualism could be associated with better repayment rates of loans taken by individuals but not by groups.

${ }^{12}$ As an alternative specification, we divide our sample into two groups according to asset size, which gives similar results.

${ }^{13}$ When we group MFIs based on assets, the only difference in the results is that the effect of trust on interest rates in larger MFIs is insignificant.

${ }^{14}$ We exclude from our analysis the last of the six indicators provided by the WGI (World Bank, 2013), that is, voice and accountability, due to its high correlation with the trust measure.

${ }^{15}$ Results with control of corruption, regulatory quality and political stability are available upon request.

${ }^{16}$ Results available upon request.

${ }^{17}$ Results available upon request. 


\section{REFERENCES}

Acemoglu D, Johnson S, Robinson JA. 2001. The colonial origins of comparative development: An empirical investigation. American Economic Review 91 (5): 13691401.

Ahlin C, Lin J, Maio M. 2011. Where does microfinance flourish? Microfinance institution performance in macroeconomic context. Journal of Development Economics 95: 105120.

Al-Azzam M, Hill RC, Sarengi S. 2012. Repayment performance in group lending: Evidence from Jordan. Journal of Development Economics 97: 404-414.

Alesina A, Devleeschauwer A, Easterly W, Kurlat S, Wacziarg R. 2003. Fractionalization. Journal of Economic Growth 8: 155-194.

Armendáriz B, Morduch J. 2010. The economics of microfinance. Second edition. Cambridge: MIT Press.

Angrist J, Chernozhukov V, Fernández-Val I. 2006. Quantile regression under misspecification, with an application to the U.S. wage structure. Econometrica 74 (2): 539-563.

Banerjee AV, Newman A.F. 1993. Occupational choice and the process of development. Journal of Political Economy 101 (2): 274-298.

Bastelaer TV, Leathers H. 2006. Trust in lending: Social capital and joint liability seed loans in Southern Zambia. World Development 34 (10): 1788-1807.

Beck T, Demirgüç-Kunt A, Levine R. 2003a. Law, endowments, and finance, Journal of Financial Economics 70 (2): 137-181. 
Beck T, Demirgüç-Kunt A, Levine R. 2003b. Law and finance: Why does legal origin matter? Journal of Comparative Economics 31: 653-675.

Beilmann M, Realo A. 2012. Individualism-collectivism and social capital at the individual level. Trames 16 (3): 205-217.

Buchinsky M. 1998. Recent advances in quantile regression models: A practical guideline for empirical research. Journal of Human Resources 33: 88-126.

Cassar A, Crowly L, Wydick B. 2007. The effects of social capital on group loan repayment: Evidence from field experiments. Economic Journal 117: 85-106.

Chui ACW, Titman S, Wei K.C.J. 2010. Individualism and momentum around the world. Journal of Finance 65 (1): 361-392.

Cull R, Demirgüç-Kunt A, Morduch J. 2007. Financial performance and outreach: A global analysis of leading microbanks. Economic Journal 117: 107-133.

Cull R, Demirgüç-Kunt A, Morduch, J. 2011. Does regulatory supervision curtail microfinance profitability and outreach? World Development 39 (6): 949-965.

Epstein MJ, Yuthas K. 2011. The critical role of trust in microfinance success: Identifying problems and solutions. Journal of Developmental Entrepreneurship 16 (4): 477-497.

Glaeser EL, Laibson DI, Sheinkman JA, Soutter CL. 2000. Measuring trust. Quarterly Journal of Economics 115 (3): 811-846.

Global Barometer Surveys. 2009. GBS - Global Barometer Surveys. Retrieved from http://www.globalbarometers.org

Gould CL. 2010. Grameencredit: One solution for poverty, but maybe not in every country. Pacific Basin Law Journal 28 (1): 1-24. 
Greif A. 1994. Cultural beliefs and the organization of society: A historical and theoretical reflection on collectivist and individualist societies. Journal of Political Economy 102 (5), 912-950.

Hartarska V, Nadolnyak D. 2007. Do regulated microfinance institutions achieve better sustainability and outreach? Cross-country evidence. Applied Economics 39: 1207-1222.

Hechter M, Opp KD. 2001. Social norms. New York: Russell Sage Foundation.

Heritage Foundation. 2013. Index of Economic Freedom. Retrieved from http://www.heritage.org/index/

Hermes N, Lensink R, Mehrteab HT. 2005. Peer monitoring, social ties and moral hazard in group lending programs: Evidence from Eritrea. World Development 33 (1): 149-169.

Hofstede G, Hofstede GJ, Minkov M. 2010. Cultures and organizations: Software of the mind: Intercultural cooperation and its importance for survival. Third edition. New York: McGraw-Hill.

Howorth C, Moro A. 2012. Trustworthiness and interest rates: An empirical study of Italian SMEs. Small Business Economics 39: 161-177.

Karlan DS. 2007. Social connections and group banking. Economic Journal, 117: 52-84.

Karlan D, Mobius M, Rosenblat T, Szeidl A. 2009. Trust and social collateral. Quarterly Journal of Economics 124 (3): 1307-1361.

Keefer P, Knack S. 2005. Social capital, social norms and the new institutional economics. In Handbook of new institutional economics, Ménard C, Shirley MM (eds). Dodrecht: Springer; 701-725.

Koenker R, Bassett GJ. 1978. Regression quantiles. Econometrica 46 (1): 33-50. 
La Porta R, Lopez-de-Silanes F, Shleifer A, Vishny R. W. 1997. Trust in large organizations. AEA Papers and Proceedings 87 (2): 333-338.

La Porta R, Lopez-de-Silanes F, Shleifer A, Vishny R. 1999. The quality of government. Journal of Law, Economics, Organization 15 (1), 222-279.

Lassen DD. 2007. Ethnic division, trust, and the size of the informal sector. Journal of Behavior Organization 63: 423-438.

Markus HR, Kitayama S. 1991. Culture and the self: Implications for cognition, emotion, and motivation. Psychological Review 98 (2): 224-253.

McEvily B, Perrone V, Zaheer A. 2003. Trust as an organizing principle. Organization Science 14 (1): 91-103.

Ménard C, Shirley MM. 2005. Handbook of new institutional economics. Dodrecht: Springer.

Mersland R, Strøm RØ. 2009. Performance and governance in microfinance institutions. Journal of Banking and Finance 33: 662-669.

Mersland R, D'Espallier B, Supphellen M. 2013. The effects of religion on development efforts: Evidence from the microfinance industry and a research agenda. World Development 41: 145-156.

Microfinance Information Exchange. 2012. MIX Market: Financial data and social performance indicators for microfinance. Retrieved from http://www.mixmarket.org

Oyserman D, Coon HM, Kemmelmeier M. 2002. Rethinking individualism and collectivism: Evaluation of theoretical assumptions and meta-analyses. Psychological Bulletin 128 (1): 3-72.

Parente PMDC, Santos Silva JMC. 2013. Quantile regression with clustered data. Discussion Paper No. 728, Department of Economics, University of Essex. 
Ray D. 1998. Development economics. Princeton: Princeton University Press.

Roberts PW. 2013. The profit orientation of microfinance institutions and effective interest rates. World Development 41: 120-131.

Uchida H, Udell GF, Yamori N. 2012. Loan officers and relationship lending to SMEs. Journal of Financial Intermediation 21: 97-122.

Vanroose A, D’Espallier B. 2013. Do microfinance institutions accomplish their mission? Evidence from the relationship between traditional financial sector development and microfinance institutions' outreach and performance. Applied Economics 45: 19651982.

Weber Y, Shenkar O, Raveh A. 1996. National and corporate cultural fit in mergers/ acquisitions: An exploratory study. Management Science 42 (8): 1215-1227.

Williamson OE. 1998. Transaction cost economics: How it works; where it is headed. De Economist 146 (1): 23-58.

World Bank. 2013. World DataBank: World Development Indicators and Worldwide Governance Indicators. Retrieved from http://data.worldbank.org

World Values Survey. 2012. World Values Survey. Retrieved from http://www.worldvaluessurvey.org 


\section{FIGURES}
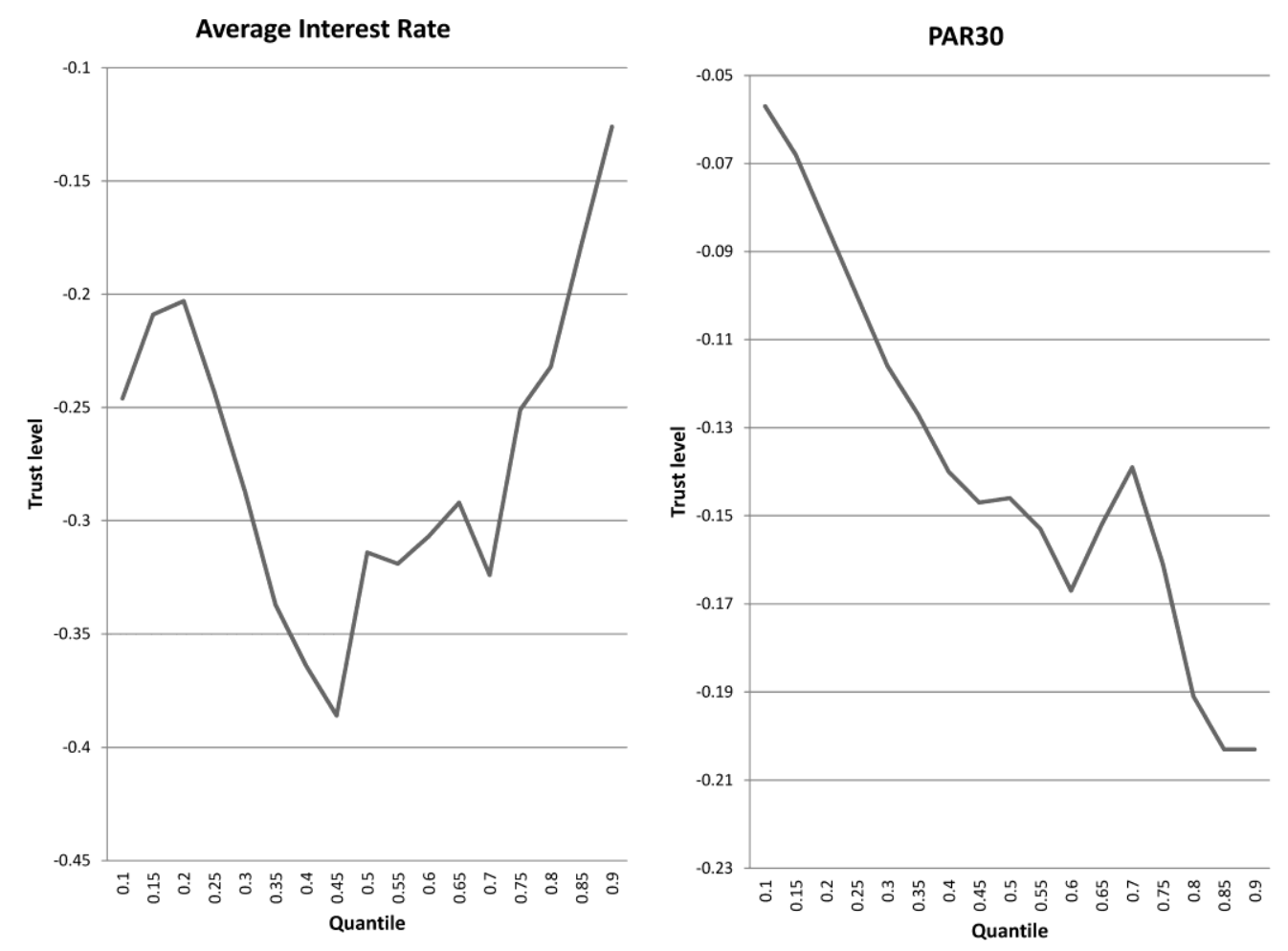

Figure 1: Impact of trust at different quantiles of significant MFI performance indicators 

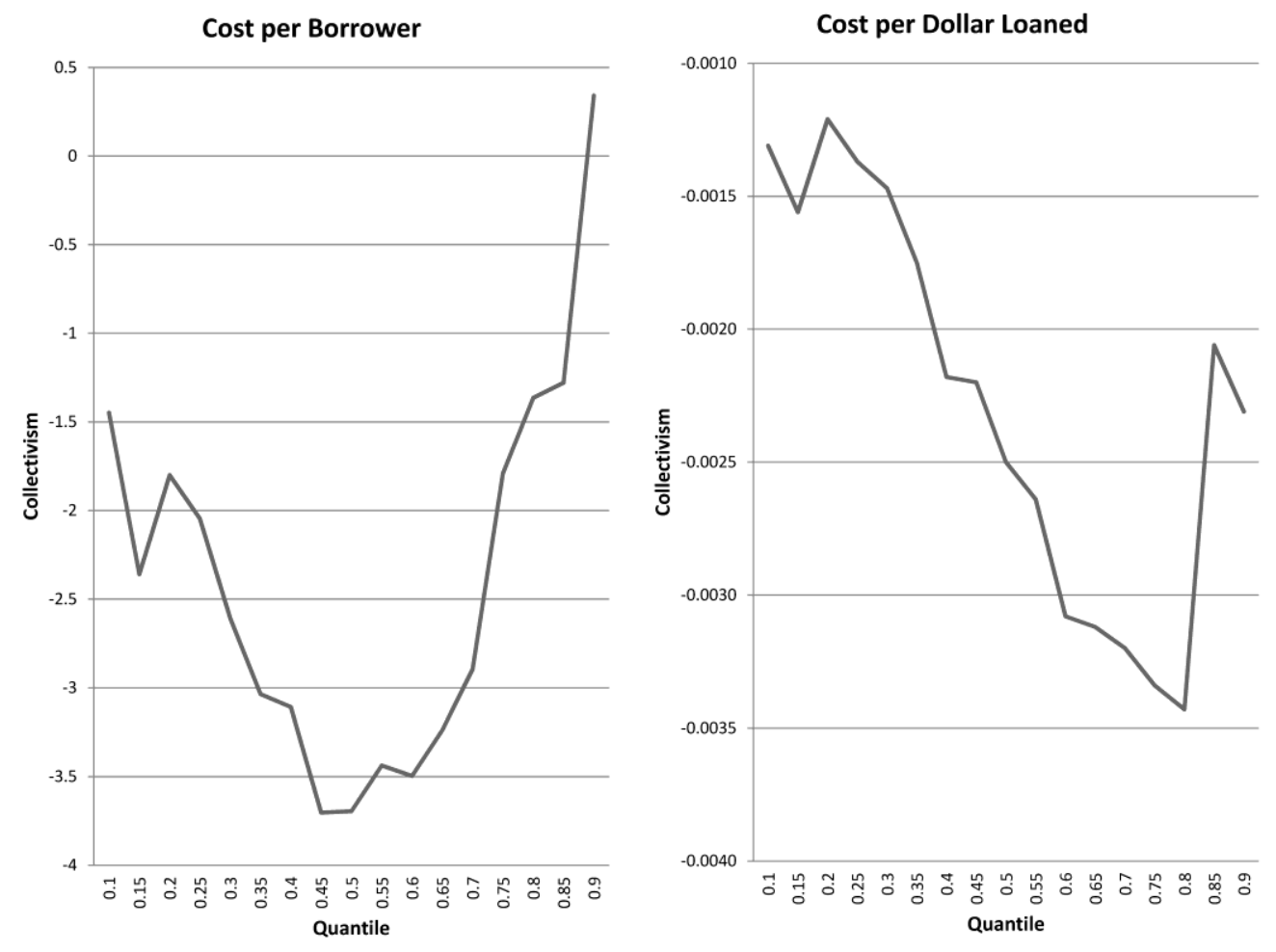

Figure 2: Impact of collectivism at different quantiles of significant MFI performance indicators 


\section{TABLES}

Table 1: Summary statistics of MFI variables used in the study

\begin{tabular}{lrrrrrr}
\hline Variable & $\mathrm{N}$ & Mean & $\mathrm{SD}$ & P25 & Median & P75 \\
\hline Average Interest Rate & 1,514 & 0.40 & 0.24 & 0.27 & 0.35 & 0.47 \\
Cost per Dollar Loaned & 1,513 & 0.28 & 0.25 & 0.13 & 0.21 & 0.34 \\
PAR30 & 1,464 & 0.07 & 0.09 & 0.02 & 0.05 & 0.08 \\
Cost per Borrower & 1,513 & 414.68 & 852.49 & 129.66 & 247.01 & 451.93 \\
Average Loan Size & 1,524 & $2,623.67$ & $8,205.80$ & 450.15 & $1,012.56$ & $2,818.66$ \\
Age & 1,524 & 15.27 & 8.54 & 9.00 & 14.00 & 20.00 \\
(Borrowers)_t-1 (1,000s) & 1,524 & 142.61 & 738.99 & 3.18 & 11.57 & 38.62 \\
(Assets per loan)_t-1 & 1,521 & 1.55 & 4.02 & 1.14 & 1.25 & 1.44 \\
Bank & 1,524 & 0.09 & 0.29 & 0.00 & 0.00 & 0.00 \\
Credit Union / Cooperative & 1,524 & 0.11 & 0.31 & 0.00 & 0.00 & 0.00 \\
NBFI & 1,524 & 0.31 & 0.46 & 0.00 & 0.00 & 1.00 \\
NGO & 1,524 & 0.44 & 0.50 & 0.00 & 0.00 & 1.00 \\
Rural Bank & 1,524 & 0.04 & 0.19 & 0.00 & 0.00 & 0.00 \\
\hline
\end{tabular}

Note: The sample consists of data from 331 MFIs in 37 countries. We require each MFI in our sample to have at least 80 per cent of its operations comprised of microfinance. 
Table 2: Social beliefs and descriptions of country-specific variables

\begin{tabular}{|c|c|c|c|c|c|c|c|c|}
\hline Variable & $\mathrm{N}$ & Mean & $\mathrm{SD}$ & $\mathrm{P} 25$ & Median & $\mathrm{P} 75$ & Min & Max \\
\hline Trust level & 1,524 & 0.21 & 0.08 & 0.15 & 0.21 & 0.25 & 0.07 & 0.56 \\
\hline Collectivism & 1,524 & 80.00 & 9.00 & 70.00 & 81.00 & 86.00 & 54.00 & 94.00 \\
\hline Rule of law & 1,524 & -0.57 & 0.44 & -0.86 & -0.61 & -0.39 & -1.43 & 1.31 \\
\hline Control of corruption & 1,524 & -0.46 & 0.41 & -0.79 & -0.49 & -0.24 & -1.49 & 1.50 \\
\hline Regulatory quality & 1,524 & -0.14 & 0.52 & -0.43 & -0.13 & 0.26 & -1.32 & 1.54 \\
\hline Government effectiveness & 1,524 & -0.30 & 0.36 & -0.58 & -0.29 & -0.02 & -0.97 & 1.27 \\
\hline Political stability & 1,524 & -0.69 & 0.68 & -0.99 & -0.74 & -0.15 & -2.73 & 0.86 \\
\hline Ethnic fractionalization & 1,524 & 0.48 & 0.21 & 0.24 & 0.54 & 0.66 & 0.05 & 0.86 \\
\hline Language fractionalization & 1,459 & 0.32 & 0.29 & 0.06 & 0.24 & 0.46 & 0.02 & 0.90 \\
\hline GDP growth & 1,524 & 0.03 & 0.03 & 0.01 & 0.04 & 0.06 & -0.08 & 0.14 \\
\hline Laborforce & 1,524 & 0.68 & 0.08 & 0.65 & 0.69 & 0.73 & 0.42 & 0.91 \\
\hline Manufacturing & 1,524 & 0.17 & 0.05 & 0.14 & 0.17 & 0.20 & 0.03 & 0.33 \\
\hline Private credit & 1,524 & 0.36 & 0.21 & 0.24 & 0.29 & 0.43 & 0.08 & 1.30 \\
\hline (GDP per capita)_t-1 & 1,524 & 6.06 & 3.36 & 3.36 & 6.10 & 7.97 & 0.53 & 14.77 \\
\hline Unfree dummy & 1,524 & 0.60 & 0.49 & 0.00 & 1.00 & 1.00 & 0.00 & 1.00 \\
\hline Colony dummy & 1,524 & 0.84 & 0.37 & 1.00 & 1.00 & 1.00 & 0.00 & 1.00 \\
\hline Low income & 1,524 & 0.07 & 0.25 & 0.00 & 0.00 & 0.00 & 0.00 & 1.00 \\
\hline Lower-middle income & 1,524 & 0.38 & 0.49 & 0.00 & 0.00 & 1.00 & 0.00 & 1.00 \\
\hline Upper-middle income & 1,524 & 0.55 & 0.50 & 0.00 & 1.00 & 1.00 & 0.00 & 1.00 \\
\hline Agriculture & 1,524 & 0.12 & 0.08 & 0.07 & 0.08 & 0.14 & 0.03 & 0.48 \\
\hline Services & 1,524 & 0.56 & 0.08 & 0.54 & 0.57 & 0.60 & 0.24 & 0.81 \\
\hline FDI & 1,524 & 0.04 & 0.04 & 0.02 & 0.03 & 0.05 & -0.00 & 0.31 \\
\hline Inflation & 1,508 & 0.06 & 0.05 & 0.03 & 0.05 & 0.08 & -0.01 & 0.51 \\
\hline $\begin{array}{l}\text { Population below poverty } \\
\text { line }\end{array}$ & 1,517 & 0.28 & 0.21 & 0.15 & 0.17 & 0.43 & 0.01 & 0.90 \\
\hline Settler mortality & 1,278 & 4.47 & 0.53 & 4.26 & 4.26 & 4.36 & 3.26 & 7.60 \\
\hline English legal origin & 1,524 & 0.13 & 0.34 & 0.00 & 0.00 & 0.00 & 0.00 & 1.00 \\
\hline French legal origin & 1,524 & 0.77 & 0.42 & 1.00 & 1.00 & 1.00 & 0.00 & 1.00 \\
\hline Socialist legal origin & 1,524 & 0.09 & 0.29 & 0.00 & 0.00 & 0.00 & 0.00 & 1.00 \\
\hline Catholic & 1,524 & 64.21 & 41.31 & 6.80 & 91.60 & 95.80 & 0.00 & 96.60 \\
\hline Muslim & 1,524 & 14.39 & 29.19 & 0.00 & 0.10 & 7.20 & 0.00 & 99.40 \\
\hline Protestant & 1,524 & 3.83 & 5.80 & 0.90 & 2.40 & 3.80 & 0.00 & 31.90 \\
\hline Other religions & 1,524 & 17.57 & 27.91 & 1.70 & 3.70 & 17.80 & 0.40 & 97.60 \\
\hline
\end{tabular}

Note: The sample consists of data from 37 countries. We require each country in our sample to have a score on trust and collectivism. 
Table 3: Trust, collectivism and MFI performance (Quantile regression with robust standard errors clustered on MFI)

\begin{tabular}{|c|c|c|c|c|}
\hline VARIABLES & $\begin{array}{c}\text { Average } \\
\text { Interest Rate }\end{array}$ & $\begin{array}{l}\text { Cost per } \\
\text { Borrower }\end{array}$ & $\begin{array}{c}\text { Cost per } \\
\text { Dollar Loaned }\end{array}$ & PAR30 \\
\hline Trust level & $\begin{array}{c}-0.314 * * * \\
(0.096)\end{array}$ & $\begin{array}{c}63.021 \\
(126.129)\end{array}$ & $\begin{array}{l}-0.148 \\
(0.126)\end{array}$ & $\begin{array}{c}-0.146 * * * \\
(0.041)\end{array}$ \\
\hline Collectivism & $\begin{array}{l}-0.001 \\
(0.105)\end{array}$ & $\begin{array}{l}-3.695 * * * \\
(125.062)\end{array}$ & $\begin{array}{c}-0.003 * * \\
(0.125)\end{array}$ & $\begin{array}{c}0.001 * * \\
(0.036)\end{array}$ \\
\hline Rule of law & $\begin{array}{l}-0.024 \\
(0.026)\end{array}$ & $\begin{array}{c}-6.946 \\
(29.570)\end{array}$ & $\begin{array}{l}-0.029 \\
(0.025)\end{array}$ & $\begin{array}{c}0.001 \\
(0.008)\end{array}$ \\
\hline Ethnic fractionalization & $\begin{array}{c}0.043 \\
(0.031)\end{array}$ & $\begin{array}{c}-140.535^{* * * *} \\
(40.296)\end{array}$ & $\begin{array}{l}-0.002 \\
(0.030)\end{array}$ & $\begin{array}{c}0.004 \\
(0.018)\end{array}$ \\
\hline GDP growth & $\begin{array}{l}-0.141 \\
(0.115)\end{array}$ & $\begin{array}{c}-302.115^{* *} \\
(147.425)\end{array}$ & $\begin{array}{c}-0.294 * * \\
(0.121)\end{array}$ & $\begin{array}{c}-0.138 * * * \\
(0.042)\end{array}$ \\
\hline Private credit & $\begin{array}{c}-0.177 * * * \\
(0.037)\end{array}$ & $\begin{array}{c}-175.543 * * * \\
(44.544)\end{array}$ & $\begin{array}{c}-0.135^{* * * *} \\
(0.042)\end{array}$ & $\begin{array}{l}-0.005 \\
(0.013)\end{array}$ \\
\hline Laborforce & $\begin{array}{c}-0.252^{* * * *} \\
(0.086)\end{array}$ & $\begin{array}{c}240.482 * * * \\
(85.891)\end{array}$ & $\begin{array}{l}-0.136^{*} \\
(0.080)\end{array}$ & $\begin{array}{l}-0.017 \\
(0.025)\end{array}$ \\
\hline Manufacturing & $\begin{array}{c}0.507 * * \\
(0.210)\end{array}$ & $\begin{array}{l}-170.878 \\
(265.543)\end{array}$ & $\begin{array}{c}0.110 \\
(0.232)\end{array}$ & $\begin{array}{c}0.204 * * * \\
(0.070)\end{array}$ \\
\hline GDP pc t-1 & $\begin{array}{l}-0.001 \\
(0.009)\end{array}$ & $\begin{array}{l}-15.981 \\
(12.083)\end{array}$ & $\begin{array}{l}-0.002 \\
(0.010)\end{array}$ & $\begin{array}{c}-0.010 * * * \\
(0.003)\end{array}$ \\
\hline$(\text { GDP pc t-1 })^{\wedge} 2$ & $\begin{array}{l}0.001 * * \\
(0.001)\end{array}$ & $\begin{array}{l}1.525^{*} \\
(0.922)\end{array}$ & $\begin{array}{c}0.001 \\
(0.001)\end{array}$ & $\begin{array}{c}0.001 * * * \\
(0.000)\end{array}$ \\
\hline Age & $\begin{array}{l}-0.000 \\
(0.000)\end{array}$ & $\begin{array}{c}0.003 \\
(0.039)\end{array}$ & $\begin{array}{c}0.000 \\
(0.000)\end{array}$ & $\begin{array}{l}-0.000 \\
(0.000)\end{array}$ \\
\hline $\operatorname{Age}^{\wedge} 2$ & $\begin{array}{c}0.002 \\
(0.004)\end{array}$ & $\begin{array}{l}-3.877 \\
(4.625)\end{array}$ & $\begin{array}{l}-0.005 \\
(0.003)\end{array}$ & $\begin{array}{l}0.003 * * \\
(0.001)\end{array}$ \\
\hline $\ln$ (Borrowers)t-1 & $\begin{array}{c}-0.014 * * * \\
(0.003)\end{array}$ & $\begin{array}{c}-27.473 * * * \\
(4.788)\end{array}$ & $\begin{array}{c}-0.021 * * * \\
(0.003)\end{array}$ & $\begin{array}{l}-0.002 \\
(0.001)\end{array}$ \\
\hline $\ln ($ Average Loan)t-1 & $\begin{array}{c}-0.080 * * * \\
(0.007)\end{array}$ & $\begin{array}{c}150.226 * * * \\
(14.727)\end{array}$ & $\begin{array}{c}-0.075^{* * * *} \\
(0.006)\end{array}$ & $\begin{array}{c}0.007 * * * \\
(0.002)\end{array}$ \\
\hline $\ln ($ Assets/Loans)t-1 & $\begin{array}{c}0.052 * * * \\
(0.014)\end{array}$ & $\begin{array}{c}65.198 * * * \\
(18.422)\end{array}$ & $\begin{array}{c}0.081 * * * \\
(0.014)\end{array}$ & $\begin{array}{c}0.011 * * \\
(0.005)\end{array}$ \\
\hline Observations & 1,519 & 1,513 & 1,518 & 1,464 \\
\hline R-squared & 0.409 & 0.209 & 0.472 & 0.131 \\
\hline MFIs & 331 & 331 & 331 & 329 \\
\hline PSS test & 26.28 & 20.36 & 26.28 & 18.95 \\
\hline $\mathrm{P}$ value & 0 & 0 & 0 & 0 \\
\hline
\end{tabular}

Note: Standard errors in parentheses; ${ }^{* * *} \mathrm{p}<0.01, * * \mathrm{p}<0.05, * \mathrm{p}<0.1$; Included in all regressions are MFI institutional-type dummies. 
Table 4: Effect of trust on average interest rates and portfolio at risk among smaller versus larger MFIs

\begin{tabular}{lcccc}
\hline \multirow{2}{*}{ VARIABLES } & \multicolumn{2}{c}{ Small MFIs } & \multicolumn{2}{c}{ Large MFIs } \\
\cline { 2 - 5 } & $\begin{array}{c}\text { Average } \\
\text { Interest Rate }\end{array}$ & PAR30 & $\begin{array}{c}\text { Average } \\
\text { Interest Rate }\end{array}$ & PAR30 \\
\hline \multirow{2}{*}{ Trust level } & & & & \\
Collectivism & $-0.431^{* * *}$ & $-0.136^{* *}$ & $-0.457^{* * *}$ & $-0.144^{* *}$ \\
& $(0.139)$ & $(0.058)$ & $(0.150)$ & $(0.061)$ \\
Rule of law & 0.001 & 0.001 & 0.001 & 0.001 \\
Ethnic fractionalization & $(0.129)$ & $(0.055)$ & $(0.209)$ & $(0.051)$ \\
& $-0.067 * *$ & 0.006 & 0.016 & 0.003 \\
GDP growth & $(0.033)$ & $(0.010)$ & $(0.041)$ & $(0.010)$ \\
& 0.077 & 0.020 & 0.014 & -0.002 \\
Private credit & $(0.055)$ & $(0.053)$ & $(0.043)$ & $(0.014)$ \\
& 0.076 & $-0.190 *$ & -0.247 & $-0.172^{* * *}$ \\
Laborforce & $(0.149)$ & $(0.106)$ & $(0.198)$ & $(0.052)$ \\
& $-0.112^{* *}$ & -0.001 & $-0.169 * *$ & -0.006 \\
Manufacturing & $(0.055)$ & $(0.020)$ & $(0.069)$ & $(0.021)$ \\
& $-0.323 * *$ & -0.093 & -0.239 & 0.001 \\
Observations & $(0.126)$ & $(0.085)$ & $(0.147)$ & $(0.031)$ \\
R-squared & 0.412 & $0.247 * *$ & $0.722^{* * *}$ & $0.146^{* *}$ \\
MFIs & $(0.273)$ & $(0.117)$ & $(0.275)$ & $(0.066)$ \\
PSS test & 735 & 713 & 759 & 728 \\
P value & 0.509 & 0.079 & 0.624 & 0.162 \\
\hline
\end{tabular}

Note: Standard errors in parentheses; $* * * \mathrm{p}<0.01,{ }^{*} \mathrm{p}<0.05,{ }^{*} \mathrm{p}<0.1$; Included in all regressions are GDP per capita controls, MFI size and age controls and MFI institutional-type dummies. 
Table 5: Effect of collectivism on average interest rates and portfolio at risk among smaller versus larger MFIs

\begin{tabular}{lcccc}
\hline \multirow{2}{*}{ VARIABLES } & \multicolumn{2}{c}{ Small MFIs } & \multicolumn{2}{c}{ Large MFIs } \\
\cline { 2 - 5 } & $\begin{array}{c}\text { Cost per } \\
\text { Borrower }\end{array}$ & $\begin{array}{c}\text { Cost per } \\
\text { Dollar Loaned }\end{array}$ & $\begin{array}{c}\text { Cost per } \\
\text { Borrower }\end{array}$ & $\begin{array}{c}\text { Cost per } \\
\text { Dollar Loaned }\end{array}$ \\
\hline \multirow{3}{*}{ Trust level } & & & & \\
& 136.857 & -0.051 & -30.350 & $-0.297^{*}$ \\
Collectivism & $(257.780)$ & $(0.171)$ & $(180.554)$ & $(0.159)$ \\
& $-4.836^{* * *}$ & $-0.003^{* *}$ & -1.384 & -0.001 \\
Rule of law & $(181.988)$ & $(0.127)$ & $(179.499)$ & $(0.263)$ \\
Ethnic fractionalization & -42.500 & -0.042 & 10.731 & -0.021 \\
& $(36.402)$ & $(0.033)$ & $(19.664)$ & $(0.058)$ \\
GDP growth & $-187.140^{* *}$ & -0.013 & $-89.838^{*}$ & 0.020 \\
Private credit & $(86.918)$ & $(0.048)$ & $(53.316)$ & $(0.053)$ \\
& -363.153 & -0.109 & -307.357 & $-0.368^{* *}$ \\
Laborforce & $(317.352)$ & $(0.172)$ & $(200.401)$ & $(0.148)$ \\
& -141.049 & $-0.167 * *$ & -137.478 & $-0.094^{*}$ \\
Manufacturing & $(93.272)$ & $(0.067)$ & $(100.702)$ & $(0.053)$ \\
& 159.419 & $-0.263 * *$ & $270.838^{* *}$ & $-0.140^{*}$ \\
Observations & $(206.570)$ & $(0.134)$ & $(125.396)$ & $(0.078)$ \\
R-squared & -515.076 & -0.110 & 104.591 & $0.522^{* *}$ \\
MFIs & $(345.873)$ & $(0.284)$ & $(229.774)$ & $(0.207)$ \\
PSS test & & & & \\
P value & 733 & 737 & 756 & 758 \\
\hline & 0.346 & 0.546 & 0.528 & 0.566 \\
& 243 & 243 & 190 & 191 \\
& 10.72 & 13.64 & 13.45 & 15.51 \\
& 0 & 0 & 0 & 0 \\
\hline
\end{tabular}

Note: Standard errors in parentheses; $* * * \mathrm{p}<0.01, * * \mathrm{p}<0.05, * \mathrm{p}<0.1$ Included in all regressions are GDP per capita controls, MFI size and age controls and MFI institutional-type dummies. 
Table 6: Split-sample regression for different organizational types (NGOs and banking institutions)

\begin{tabular}{|c|c|c|c|c|c|c|c|c|}
\hline \multirow[b]{2}{*}{ VARIABLES } & \multicolumn{4}{|c|}{ Banking institutions } & \multicolumn{4}{|c|}{ NGOs } \\
\hline & $\begin{array}{c}\text { Average } \\
\text { Interest } \\
\text { Rate }\end{array}$ & $\begin{array}{l}\text { Cost per } \\
\text { Borrower }\end{array}$ & $\begin{array}{l}\text { Cost per } \\
\text { Dollar } \\
\text { Loaned } \\
\end{array}$ & PAR30 & $\begin{array}{c}\text { Average } \\
\text { Interest } \\
\text { Rate }\end{array}$ & $\begin{array}{l}\text { Cost per } \\
\text { Borrower }\end{array}$ & $\begin{array}{c}\text { Cost per } \\
\text { Dollar } \\
\text { Loaned }\end{array}$ & PAR30 \\
\hline Trust level & $\begin{array}{c}-0.396 * * \\
(0.198)\end{array}$ & $\begin{array}{c}313.658 \\
(272.839)\end{array}$ & $\begin{array}{c}0.005 \\
(0.191)\end{array}$ & $\begin{array}{c}-0.282 * * * \\
(0.057)\end{array}$ & $\begin{array}{c}-0.207 \\
(0.182)\end{array}$ & $\begin{array}{c}14.449 \\
(99.486)\end{array}$ & $\begin{array}{l}-0.007 \\
(0.256)\end{array}$ & $\begin{array}{c}-0.130 * * \\
(0.051)\end{array}$ \\
\hline Collectivism & $\begin{array}{c}0.002 \\
(0.176)\end{array}$ & $\begin{array}{c}-6.252 * \\
(323.749)\end{array}$ & $\begin{array}{c}0.000 \\
(0.175)\end{array}$ & $\begin{array}{l}0.001 * \\
(0.060)\end{array}$ & $\begin{array}{c}-0.005 * * * \\
(0.196)\end{array}$ & $\begin{array}{c}-2.518 \\
(153.888)\end{array}$ & $\begin{array}{c}-0.006 * * * \\
(0.191)\end{array}$ & $\begin{array}{c}0.001 \\
(0.057)\end{array}$ \\
\hline Observations & 611 & 608 & 610 & 593 & 669 & 668 & 669 & 641 \\
\hline R-squared & 0.333 & 0.245 & 0.517 & 0.091 & 0.450 & 0.180 & 0.444 & 0.119 \\
\hline MFIs & 128 & 128 & 128 & 128 & 141 & 141 & 141 & 140 \\
\hline PSS test & 17.45 & 11.70 & 13.03 & 10.68 & 16.95 & 14.78 & 17.44 & 11.92 \\
\hline $\mathrm{P}$ value & 0 & 0 & 0 & 0 & 0 & 0 & 0 & 0 \\
\hline
\end{tabular}

Note: Standard errors in parentheses; $* * * \mathrm{p}<0.01, * * \mathrm{p}<0.05, * \mathrm{p}<0.1$; Included in all regressions are all baseline controls (see Table 3). 
Table 7: Government effectiveness, social beliefs and MFI performance

\begin{tabular}{lcccc}
\hline VARIABLES & $\begin{array}{c}\text { Average } \\
\text { Interest Rate }\end{array}$ & $\begin{array}{c}\text { Cost per } \\
\text { Borrower }\end{array}$ & $\begin{array}{c}\text { Cost per } \\
\text { Dollar Loaned }\end{array}$ & PAR30 \\
\hline Trust level & & & & \\
& $-0.302^{* * *}$ & 58.232 & -0.100 & $-0.167 * * *$ \\
Collectivism & $(0.111)$ & $(117.239)$ & $(0.112)$ & $(0.043)$ \\
& -0.001 & $-3.507 * * *$ & $-0.002^{* *}$ & $0.001 * *$ \\
Government effectiveness & $(0.106)$ & $(111.640)$ & $(0.101)$ & $(0.036)$ \\
& 0.005 & 4.846 & 0.029 & -0.009 \\
Ethnic fractionalization & $(0.030)$ & $(32.690)$ & $(0.030)$ & $(0.010)$ \\
& 0.041 & $-145.335^{* * *}$ & -0.017 & 0.008 \\
GDP growth & $(0.032)$ & $(40.450)$ & $(0.032)$ & $(0.018)$ \\
& $-0.192^{*}$ & $-288.156^{* *}$ & $-0.425 * * *$ & $-0.132^{* * *}$ \\
Private credit & $(0.110)$ & $(142.316)$ & $(0.107)$ & $(0.046)$ \\
& $-0.195 * * *$ & $-180.370 * * *$ & $-0.179 * * *$ & 0.005 \\
Laborforce & $(0.041)$ & $(41.344)$ & $(0.041)$ & $(0.014)$ \\
& $-0.207 * * *$ & $256.984 * * *$ & -0.058 & -0.023 \\
Manufacturing & $(0.077)$ & $(77.438)$ & $(0.060)$ & $(0.025)$ \\
& 0.434 & -167.438 & -0.049 & $0.238^{* * *}$ \\
Observations & $(0.284)$ & $(253.218)$ & $(0.290)$ & $(0.080)$ \\
R-squared & 1,519 & 1,513 & & \\
MFIs & 0.407 & 0.209 & 1,518 & 1,464 \\
PSS test & 331 & 331 & 0.468 & 0.134 \\
P value & 26.84 & 20.01 & 331 & 329 \\
\hline
\end{tabular}

Note: Standard errors in parentheses; ${ }^{* * *} \mathrm{p}<0.01,{ }^{* *} \mathrm{p}<0.05,{ }^{*} \mathrm{p}<0.1$; Included in all regressions are GDP per capita controls, MFI size and age controls and MFI institutional-type dummies. 
Table 8: Colonialism, social beliefs and MFI performance

\begin{tabular}{|c|c|c|c|c|}
\hline VARIABLES & $\begin{array}{c}\text { Average } \\
\text { Interest Rate }\end{array}$ & $\begin{array}{l}\text { Cost per } \\
\text { Borrower }\end{array}$ & $\begin{array}{c}\text { Cost per } \\
\text { Dollar Loaned }\end{array}$ & PAR30 \\
\hline Trust level & $\begin{array}{l}-0.182 \\
(0.149)\end{array}$ & $\begin{array}{c}9.000 \\
(182.135)\end{array}$ & $\begin{array}{l}-0.043 \\
(0.144)\end{array}$ & $\begin{array}{c}-0.177 * * * \\
(0.057)\end{array}$ \\
\hline Collectivism & $\begin{array}{l}-0.002 \\
(0.175)\end{array}$ & $\begin{array}{l}-3.025 * * * \\
(112.199)\end{array}$ & $\begin{array}{l}-0.002 \\
(0.135)\end{array}$ & $\begin{array}{c}0.001 * * \\
(0.042)\end{array}$ \\
\hline Settler mortality & $\begin{array}{c}0.060 * * \\
(0.029)\end{array}$ & $\begin{array}{c}49.894 \\
(30.402)\end{array}$ & $\begin{array}{c}0.072 * * * \\
(0.017)\end{array}$ & $\begin{array}{l}-0.003 \\
(0.007)\end{array}$ \\
\hline Rule of law & $\begin{array}{c}-0.072 * * \\
(0.031)\end{array}$ & $\begin{array}{c}-39.642^{*} \\
(21.164)\end{array}$ & $\begin{array}{c}-0.075^{* * *} \\
(0.027)\end{array}$ & $\begin{array}{c}0.001 \\
(0.009)\end{array}$ \\
\hline Ethnic fractionalization & $\begin{array}{c}0.013 \\
(0.037)\end{array}$ & $\begin{array}{c}-155.210^{* * * *} \\
(49.884)\end{array}$ & $\begin{array}{l}-0.015 \\
(0.038)\end{array}$ & $\begin{array}{l}-0.006 \\
(0.024)\end{array}$ \\
\hline GDP growth & $\begin{array}{c}0.047 \\
(0.131)\end{array}$ & $\begin{array}{c}-286.617 * * \\
(144.300)\end{array}$ & $\begin{array}{l}-0.070 \\
(0.117)\end{array}$ & $\begin{array}{c}-0.133 * * * \\
(0.051)\end{array}$ \\
\hline Private credit & $\begin{array}{c}-0.172 * * * \\
(0.049)\end{array}$ & $\begin{array}{c}-170.957 * * * \\
(58.012)\end{array}$ & $\begin{array}{c}-0.134 * * * \\
(0.050)\end{array}$ & $\begin{array}{l}-0.004 \\
(0.016)\end{array}$ \\
\hline Laborforce & $\begin{array}{c}-0.340 * * * \\
(0.089)\end{array}$ & $\begin{array}{c}191.551 \\
(116.551)\end{array}$ & $\begin{array}{c}-0.273 * * * \\
(0.083)\end{array}$ & $\begin{array}{l}-0.042 \\
(0.041)\end{array}$ \\
\hline Manufacturing & $\begin{array}{l}0.365 * \\
(0.200)\end{array}$ & $\begin{array}{c}-39.596 \\
(376.595)\end{array}$ & $\begin{array}{c}0.289 \\
(0.194)\end{array}$ & $\begin{array}{c}0.174 \\
(0.108)\end{array}$ \\
\hline Observations & 1,274 & 1,270 & 1,273 & 1,229 \\
\hline R-squared & 0.411 & 0.212 & 0.492 & 0.181 \\
\hline MFIs & 281 & 281 & 281 & 280 \\
\hline PSS test & 25.25 & 15.77 & 23.24 & 18.73 \\
\hline P value & 0 & 0 & 0 & 0 \\
\hline
\end{tabular}


Table 9: Legal origin, social beliefs and MFI performance

\begin{tabular}{|c|c|c|c|c|}
\hline VARIABLES & $\begin{array}{c}\text { Average } \\
\text { Interest Rate }\end{array}$ & $\begin{array}{l}\text { Cost per } \\
\text { Borrower }\end{array}$ & $\begin{array}{c}\text { Cost per } \\
\text { Dollar Loaned } \\
\end{array}$ & PAR30 \\
\hline Trust level & $\begin{array}{c}-0.221 * * \\
(0.094)\end{array}$ & $\begin{array}{c}-91.454 \\
(154.230)\end{array}$ & $\begin{array}{l}-0.052 \\
(0.141)\end{array}$ & $\begin{array}{c}-0.124 * * \\
(0.052)\end{array}$ \\
\hline Collectivism & $\begin{array}{l}-0.002 * \\
(0.114)\end{array}$ & $\begin{array}{l}-3.032 * * \\
(121.625)\end{array}$ & $\begin{array}{c}-0.003 * * \\
(0.138)\end{array}$ & $\begin{array}{l}0.001 * \\
(0.044)\end{array}$ \\
\hline Rule of law & $\begin{array}{l}-0.042 \\
(0.028)\end{array}$ & $\begin{array}{c}6.354 \\
(25.839)\end{array}$ & $\begin{array}{l}-0.033 \\
(0.024)\end{array}$ & $\begin{array}{l}-0.003 \\
(0.009)\end{array}$ \\
\hline Ethnic fractionalization & $\begin{array}{c}0.061 * * \\
(0.029)\end{array}$ & $\begin{array}{c}-143.804 * * * \\
(35.207)\end{array}$ & $\begin{array}{c}0.005 \\
(0.030)\end{array}$ & $\begin{array}{l}-0.008 \\
(0.019)\end{array}$ \\
\hline GDP growth & $\begin{array}{l}-0.003 \\
(0.101)\end{array}$ & $\begin{array}{c}-397.674 * * * \\
(154.023)\end{array}$ & $\begin{array}{c}-0.287 * * \\
(0.124)\end{array}$ & $\begin{array}{c}-0.126 * * * \\
(0.041)\end{array}$ \\
\hline Private credit & $\begin{array}{c}-0.150 * * * \\
(0.040)\end{array}$ & $\begin{array}{c}-251.966 * * * \\
(70.869)\end{array}$ & $\begin{array}{c}-0.132 * * * \\
(0.045)\end{array}$ & $\begin{array}{c}0.008 \\
(0.013)\end{array}$ \\
\hline Laborforce & $\begin{array}{c}-0.213 * * \\
(0.094)\end{array}$ & $\begin{array}{c}68.938 \\
(121.117)\end{array}$ & $\begin{array}{l}-0.067 \\
(0.091)\end{array}$ & $\begin{array}{c}0.013 \\
(0.030)\end{array}$ \\
\hline Manufacturing & $\begin{array}{c}0.358 \\
(0.222)\end{array}$ & $\begin{array}{c}-28.493 \\
(326.933)\end{array}$ & $\begin{array}{c}0.007 \\
(0.231)\end{array}$ & $\begin{array}{c}0.215 * * * \\
(0.068)\end{array}$ \\
\hline English legal origin & $\begin{array}{c}-0.086 * * \\
(0.038)\end{array}$ & $\begin{array}{c}55.653 \\
(46.758)\end{array}$ & $\begin{array}{l}-0.051^{*} \\
(0.026)\end{array}$ & $\begin{array}{c}0.018 \\
(0.013)\end{array}$ \\
\hline Socialist legal origin & $\begin{array}{c}-0.065^{* *} * \\
(0.026)\end{array}$ & $\begin{array}{l}155.230^{*} \\
(79.172)\end{array}$ & $\begin{array}{l}-0.042 \\
(0.036)\end{array}$ & $\begin{array}{c}-0.017 \\
(0.011)\end{array}$ \\
\hline Observations & 1,519 & 1,513 & 1,518 & 1,464 \\
\hline R-squared & 0.416 & 0.204 & 0.478 & 0.136 \\
\hline MFIs & 331 & 331 & 331 & 329 \\
\hline PSS test & 25.02 & 19.62 & 26.53 & 19.09 \\
\hline $\mathrm{P}$ value & 0 & 0 & 0 & 0 \\
\hline
\end{tabular}

Note: Standard errors in parentheses; *** $\mathrm{p}<0.01,{ }^{*} \mathrm{p}<0.05,{ }^{*} \mathrm{p}<0.1$; Included in all regressions are GDP per capita controls, MFI size and age controls and MFI institutional-type dummies. 
Table 10: Economic freedom, social beliefs and MFI performance

\begin{tabular}{|c|c|c|c|c|}
\hline VARIABLES & $\begin{array}{c}\text { Average } \\
\text { Interest Rate }\end{array}$ & $\begin{array}{l}\text { Cost per } \\
\text { Borrower }\end{array}$ & $\begin{array}{c}\text { Cost per } \\
\text { Dollar Loaned }\end{array}$ & PAR30 \\
\hline Trust level & $\begin{array}{c}-0.295^{* * *} * \\
(0.099)\end{array}$ & $\begin{array}{c}96.070 \\
(118.136)\end{array}$ & $\begin{array}{l}-0.065 \\
(0.120)\end{array}$ & $\begin{array}{c}-0.140 * * * \\
(0.044)\end{array}$ \\
\hline Collectivism & $\begin{array}{l}-0.001 \\
(0.105)\end{array}$ & $\begin{array}{l}-3.596 * * * \\
(110.820)\end{array}$ & $\begin{array}{c}-0.003 * * \\
(0.113)\end{array}$ & $\begin{array}{c}0.001 * * \\
(0.036)\end{array}$ \\
\hline Rule of law & $\begin{array}{l}-0.023 \\
(0.024)\end{array}$ & $\begin{array}{c}-2.683 \\
(26.134)\end{array}$ & $\begin{array}{l}-0.031 \\
(0.021)\end{array}$ & $\begin{array}{c}0.001 \\
(0.008)\end{array}$ \\
\hline Unfree & $\begin{array}{l}-0.057^{*} \\
(0.033)\end{array}$ & $\begin{array}{c}-34.777 \\
(24.395)\end{array}$ & $\begin{array}{c}-0.086^{* * *} \\
(0.034)\end{array}$ & $\begin{array}{l}-0.005 \\
(0.007)\end{array}$ \\
\hline Ethnic fractionalization & $\begin{array}{c}0.020 \\
(0.037)\end{array}$ & $\begin{array}{c}-157.562 * * * \\
(41.218)\end{array}$ & $\begin{array}{l}-0.032 \\
(0.030)\end{array}$ & $\begin{array}{c}0.004 \\
(0.018)\end{array}$ \\
\hline GDP growth & $\begin{array}{l}-0.115 \\
(0.105)\end{array}$ & $\begin{array}{c}-258.485^{*} \\
(141.090)\end{array}$ & $\begin{array}{c}-0.221 * * \\
(0.106)\end{array}$ & $\begin{array}{c}-0.136 * * * \\
(0.043)\end{array}$ \\
\hline Private credit & $\begin{array}{c}-0.190 * * * \\
(0.037)\end{array}$ & $\begin{array}{c}-186.648 * * * \\
(43.282)\end{array}$ & $\begin{array}{c}-0.158 * * * \\
(0.039)\end{array}$ & $\begin{array}{l}-0.005 \\
(0.014)\end{array}$ \\
\hline Laborforce & $\begin{array}{c}-0.228 * * \\
(0.104)\end{array}$ & $\begin{array}{c}264.547 * * * \\
(86.363)\end{array}$ & $\begin{array}{l}-0.094 \\
(0.071)\end{array}$ & $\begin{array}{l}-0.016 \\
(0.027)\end{array}$ \\
\hline Manufacturing & $\begin{array}{c}0.447 * * \\
(0.225)\end{array}$ & $\begin{array}{l}-229.647 \\
(269.781)\end{array}$ & $\begin{array}{c}-0.032 \\
(0.213)\end{array}$ & $\begin{array}{c}0.197 * * * \\
(0.074)\end{array}$ \\
\hline Observations & 1,519 & 1,513 & 1,518 & 1,464 \\
\hline MFIs & 331 & 331 & 331 & 329 \\
\hline PSS test & 26.11 & 19.94 & 26.88 & 18.94 \\
\hline P value & 0 & 0 & 0 & 0 \\
\hline
\end{tabular}

Note: Standard errors in parentheses; $* * * \mathrm{p}<0.01, * * \mathrm{p}<0.05, * \mathrm{p}<0.1$; Included in all regressions are GDP per capita controls, MFI size and age controls and MFI institutional-type dummies. 
Table 11: Income group, social beliefs and MFI performance

\begin{tabular}{|c|c|c|c|c|}
\hline VARIABLES & $\begin{array}{c}\text { Average } \\
\text { Interest Rate }\end{array}$ & $\begin{array}{l}\text { Cost per } \\
\text { Borrower }\end{array}$ & $\begin{array}{c}\text { Cost per } \\
\text { Dollar Loaned }\end{array}$ & PAR30 \\
\hline Trust level & $\begin{array}{c}-0.383 * * * \\
(0.099)\end{array}$ & $\begin{array}{c}71.651 \\
(120.021)\end{array}$ & $\begin{array}{l}-0.184 \\
(0.121)\end{array}$ & $\begin{array}{c}-0.132 * * * \\
(0.048)\end{array}$ \\
\hline Collectivism & $\begin{array}{l}-0.001 \\
(0.108)\end{array}$ & $\begin{array}{l}-3.732 * * * \\
(124.411)\end{array}$ & $\begin{array}{c}-0.003 * * \\
(0.111)\end{array}$ & $\begin{array}{c}0.001 * * \\
(0.039)\end{array}$ \\
\hline Rule of law & $\begin{array}{l}-0.047^{*} \\
(0.024)\end{array}$ & $\begin{array}{c}-6.498 \\
(29.536)\end{array}$ & $\begin{array}{c}-0.042 * \\
(0.022)\end{array}$ & $\begin{array}{c}0.003 \\
(0.009)\end{array}$ \\
\hline Low-income & $\begin{array}{c}-0.141 * * \\
(0.057)\end{array}$ & $\begin{array}{l}-43.276 \\
(50.249)\end{array}$ & $\begin{array}{c}-0.121 * * \\
(0.048)\end{array}$ & $\begin{array}{c}0.035 \\
(0.024)\end{array}$ \\
\hline Lower-middle income & $\begin{array}{l}-0.006 \\
(0.022)\end{array}$ & $\begin{array}{l}-17.406 \\
(34.523)\end{array}$ & $\begin{array}{l}-0.003 \\
(0.024)\end{array}$ & $\begin{array}{c}0.009 \\
(0.013)\end{array}$ \\
\hline Ethnic fractionalization & $\begin{array}{c}0.043 \\
(0.035)\end{array}$ & $\begin{array}{c}-160.246 * * * \\
(47.542)\end{array}$ & $\begin{array}{c}0.009 \\
(0.027)\end{array}$ & $\begin{array}{c}0.010 \\
(0.021)\end{array}$ \\
\hline GDP growth & $\begin{array}{l}-0.066 \\
(0.103)\end{array}$ & $\begin{array}{c}-353.314 * * \\
(162.896)\end{array}$ & $\begin{array}{c}-0.231 * * \\
(0.115)\end{array}$ & $\begin{array}{c}-0.131 * * * \\
(0.044)\end{array}$ \\
\hline Private credit & $\begin{array}{c}-0.172 * * * \\
(0.032)\end{array}$ & $\begin{array}{c}-182.716 * * * \\
(44.632)\end{array}$ & $\begin{array}{c}-0.135^{* * *} * \\
(0.040)\end{array}$ & $\begin{array}{l}-0.007 \\
(0.013)\end{array}$ \\
\hline Laborforce & $\begin{array}{c}-0.267 * * * \\
(0.088)\end{array}$ & $\begin{array}{c}249.609 * * * \\
(83.464)\end{array}$ & $\begin{array}{c}-0.160 * * \\
(0.077)\end{array}$ & $\begin{array}{l}-0.013 \\
(0.028)\end{array}$ \\
\hline Manufacturing & $\begin{array}{l}0.387^{*} \\
(0.209)\end{array}$ & $\begin{array}{l}-224.702 \\
(282.487)\end{array}$ & $\begin{array}{l}-0.040 \\
(0.205)\end{array}$ & $\begin{array}{c}0.212 * * * \\
(0.079)\end{array}$ \\
\hline Observations & 1,519 & 1,513 & 1,518 & 1,464 \\
\hline MFIs & 331 & 331 & 331 & 329 \\
\hline PSS test & 25.21 & 20.09 & 25.61 & 18.40 \\
\hline $\mathrm{P}$ value & 0 & 0 & 0 & 0 \\
\hline
\end{tabular}

Note: Standard errors in parentheses; $* * * \mathrm{p}<0.01, * * \mathrm{p}<0.05, * \mathrm{p}<0.1$ Included in all regressions are GDP per capita controls, MFI size and age controls and MFI institutional-type dummies. 
Table 12: Social beliefs and MFI performance (Sample excluding countries with the percentage of Muslim population above 90 per cent)

\begin{tabular}{|c|c|c|c|c|}
\hline VARIABLES & $\begin{array}{c}\text { Average } \\
\text { Interest Rate }\end{array}$ & $\begin{array}{l}\text { Cost per } \\
\text { Borrower }\end{array}$ & $\begin{array}{c}\text { Cost per } \\
\text { Dollar Loaned }\end{array}$ & PAR30 \\
\hline Trust level & $\begin{array}{c}-0.356^{* * * *} \\
(0.119)\end{array}$ & $\begin{array}{c}8.087 \\
(128.210)\end{array}$ & $\begin{array}{l}-0.168 \\
(0.198)\end{array}$ & $\begin{array}{c}-0.134 * * * \\
(0.045)\end{array}$ \\
\hline Collectivism & $\begin{array}{l}-0.001 \\
(0.112)\end{array}$ & $\begin{array}{l}-3.498 * * * \\
(132.661)\end{array}$ & $\begin{array}{l}-0.002 * \\
(0.129)\end{array}$ & $\begin{array}{c}0.001 * * \\
(0.037)\end{array}$ \\
\hline Rule of law & $\begin{array}{l}-0.040 \\
(0.034)\end{array}$ & $\begin{array}{c}-6.398 \\
(33.846)\end{array}$ & $\begin{array}{l}-0.042 \\
(0.032)\end{array}$ & $\begin{array}{c}0.000 \\
(0.008)\end{array}$ \\
\hline Ethnic fractionalization & $\begin{array}{c}0.054 \\
(0.046)\end{array}$ & $\begin{array}{c}-200.535^{* * * *} \\
(55.494)\end{array}$ & $\begin{array}{l}-0.029 \\
(0.077)\end{array}$ & $\begin{array}{c}0.026 \\
(0.026)\end{array}$ \\
\hline GDP growth & $\begin{array}{c}-0.123 \\
(0.129)\end{array}$ & $\begin{array}{c}-262.403^{*} \\
(147.256)\end{array}$ & $\begin{array}{l}-0.273^{*} \\
(0.139)\end{array}$ & $\begin{array}{c}-0.140 * * * \\
(0.042)\end{array}$ \\
\hline Private credit & $\begin{array}{c}-0.159 * * * \\
(0.054)\end{array}$ & $\begin{array}{c}-202.197 * * * \\
(53.129)\end{array}$ & $\begin{array}{l}-0.142 \\
(0.094)\end{array}$ & $\begin{array}{c}0.008 \\
(0.013)\end{array}$ \\
\hline Laborforce & $\begin{array}{c}-0.332 * * \\
(0.148)\end{array}$ & $\begin{array}{c}369.203 * * * \\
(99.231)\end{array}$ & $\begin{array}{l}-0.095 \\
(0.228)\end{array}$ & $\begin{array}{l}-0.080^{*} \\
(0.044)\end{array}$ \\
\hline Manufacturing & $\begin{array}{c}0.587 * * * \\
(0.217)\end{array}$ & $\begin{array}{l}-253.159 \\
(277.363)\end{array}$ & $\begin{array}{c}0.073 \\
(0.371)\end{array}$ & $\begin{array}{c}0.237 * * * \\
(0.078)\end{array}$ \\
\hline Observations & 1,415 & 1,411 & 1,414 & 1,364 \\
\hline R-squared & 0.403 & 0.208 & 0.471 & 0.141 \\
\hline MFIs & 308 & 308 & 308 & 307 \\
\hline PSS test & 26.34 & 19.27 & 26.36 & 17.92 \\
\hline $\mathrm{P}$ value & 0 & 0 & 0 & 0 \\
\hline
\end{tabular}

Note: Standard errors in parentheses; $* * * \mathrm{p}<0.01$, $* * \mathrm{p}<0.05, * \mathrm{p}<0.1$; Included in all regressions are GDP per capita controls, MFI size and age controls and MFI institutional-type dummies. 


\section{APPENDIX}

Table A1: List of countries included in the study (2003-2011)

\begin{tabular}{|c|c|c|c|}
\hline Country & $\begin{array}{c}\text { Trust level, } \\
\text { average }(\%)\end{array}$ & $\begin{array}{l}\text { Collectivism index } \\
\quad(100-I D V)\end{array}$ & $\begin{array}{l}\text { Number of MFIs } \\
\text { included in study }\end{array}$ \\
\hline Albania & 24 & 80 & 5 \\
\hline Argentina & 21 & 54 & 8 \\
\hline Bangladesh & 24 & 80 & 8 \\
\hline Brazil & 7 & 62 & 15 \\
\hline Bulgaria & 25 & 70 & 7 \\
\hline Burkina Faso & 15 & 85 & 2 \\
\hline Chile & 15 & 77 & 3 \\
\hline China & 56 & 80 & 2 \\
\hline Colombia & 17 & 87 & 21 \\
\hline Costa Rica & 16 & 85 & 10 \\
\hline Dominican Republic & 27 & 70 & 4 \\
\hline Ecuador & 21 & 92 & 42 \\
\hline Egypt & 28 & 75 & 8 \\
\hline El Salvador & 23 & 81 & 13 \\
\hline Ethiopia & 24 & 80 & 1 \\
\hline Ghana & 12 & 85 & 10 \\
\hline Guatemala & 25 & 94 & 16 \\
\hline Honduras & 20 & 80 & 16 \\
\hline Indonesia & 30 & 86 & 14 \\
\hline Jordan & 32 & 70 & 7 \\
\hline Kenya & 10 & 75 & 11 \\
\hline Lebanon & 16 & 60 & 2 \\
\hline Malawi & 26 & 70 & 2 \\
\hline Mexico & 22 & 70 & 26 \\
\hline Morocco & 20 & 75 & 2 \\
\hline Nigeria & 16 & 70 & 2 \\
\hline Pakistan & 40 & 86 & 13 \\
\hline Panama & 21 & 89 & 3 \\
\hline Peru & 15 & 84 & 34 \\
\hline Philippines & 10 & 68 & 38 \\
\hline Romania & 15 & 70 & 3 \\
\hline Russia & 25 & 61 & 4 \\
\hline Senegal & 27 & 75 & 4 \\
\hline Sri Lanka & 18 & 65 & 6 \\
\hline Tanzania & 11 & 75 & 4 \\
\hline Vietnam & 39 & 80 & 13 \\
\hline Zambia & 14 & 65 & 2 \\
\hline
\end{tabular}




\section{The Impact of Social Beliefs on Microfinance Performance}

\section{OLLE BERGGREN | KATARZYNA BURZYNSKA}

We apply a panel of 331 microfinance institutions from 37 countries to investigate the relationship between social beliefs and microfinance financial performance. We find that microfinance institutions in countries with higher levels of trust and more collectivist culture have lower operating and default costs and charge lower interest rates. These results provide the first large cross-country evidence that social beliefs are important determinants of microfinance performance.

Keywords: microfinance; performance; informal institutions; trust; collectivism

JEL: 016; 017; 050; G21, 043

\section{THE KNUT WICKSELL CENTRE FOR FINANCIAL STUDIES}

The Knut Wicksell Centre for Financial Studies conducts cutting-edge research in financial economics and related academic disciplines. Established in 2011, the Centre is a collaboration between Lund University School of Economics and Management and the Research Institute of Industrial Economics (IFN) in Stockholm. The Centre supports research projects, arranges seminars, and organizes conferences. A key goal of the Centre is to foster interaction between academics, practitioners and students to better understand current topics related to financial markets. 